\title{
Selective B cell depletion upon intravenous infusion of replication- incompetent anti-CD19 CAR lentivirus
}

\author{
Craig M. Rive ${ }^{\mathrm{a}, 1}$, Eric Yung ${ }^{\mathrm{a}, 1}$, Lisa Dreolini ${ }^{\mathrm{a}}$, Daniel J. Woodsworth ${ }^{\mathrm{a}}$, Robert A. Holt ${ }^{\text {a,b,c,2 }}$ \\ ${ }^{a}$ Canada's Michael Smith Genome Sciences Centre, BC Cancer, Vancouver, BC, V5Z 1L3, Canada. \\ ${ }^{\mathrm{b}}$ Department of Medical Genetics, University of British Columbia, Vancouver, BC, V6T 1Z4, Canada. \\ ${ }^{\mathrm{c}}$ Molecular Biology \& Biochemistry, Simon Fraser University, Burnaby, BC, V5A 1S6, Canada. \\ ${ }^{1}$ Co-first author \\ ${ }^{2}$ Correspondence: rholt@bcgsc.ca, Canada's Michael Smith Genome Sciences Centre, BC Cancer, Vancouver, British Columbia, \\ Canada
}

\begin{abstract}
Anti-CD19 CAR-T therapy for B cell malignancies has shown clinical success, but a major limitation is the logistical complexity and high cost of manufacturing autologous cell products. Direct infusion of viral gene transfer vectors to initiate in vivo CAR-T transduction, expansion and anti-tumor activity could provide an alternative, universal approach for CAR-T and related immune effector cell therapies that circumvents ex vivo cell manufacturing. To explore the potential of this approach we first evaluated human and murine $\mathrm{CD}^{+} \mathrm{T}$ cells transduced with VSV-G pseudotyped lentivectors carrying an anti-CD19CAR-2A-GFP transgene comprising either an FMC63 (human) or 1D3 (murine) anti-CD19 binding domain. To evaluate CD19 antigen-driven CAR-T proliferation in vitro we co-cultured transduced murine $\mathrm{T}$ cells with an excess of irradiated splenocytes and observed robust expansion over a 9 week period relative to control T cells transduced with a GFP transgene (mean fold expansion +/- SD: ID3-CD19CAR-GFP modified T cells, 12.2 +/- 0.09 ( $<<0.001$ ); FMC63-CD19CAR-GFP modified T cells $8.8+/-0.03$ (p < 0.001). CAR-T cells isolated at the end of the expansion period showed potent B cell directed cytolytic activity in vitro. Next, we administered approximately 20 million replication-incompetent lentiviral particles carrying either ID3-CD19CAR-GFP, FMC63CD19CAR-GFP, or GFP-only transgene to to wild-type C57BL/6 mice by tail vein infusion and monitored the dynamics of immune cell subsets isolated from peripheral blood at weekly intervals. We saw emergence of a persistent CAR-transduced CD3 ${ }^{+}$ $\mathrm{T}$ cell population beginning week $3-4$ that reaching a maximum of $13.5+/-0.58 \%$ (mean $+/-\mathrm{SD}$ ) and $7.8+/-0.76 \%$ of the peripheral blood $\mathrm{CD}^{+} \mathrm{T}$ cell population in mice infused with ID3-CD19CAR-GFP lentivector or FMC63-CD19CAR-GFP lentivector, respectively, followed by a rapid decline, in each case of, the B cell content of peripheral blood. Complete B cell aplasia was apparent by week 5 and was sustained until the end of the protocol (week 8). None of these changes were observed in mice infused with GFP-only control lentivector, and significant CAR positive populations were not observed within other immune cell subsets, including macrophage, natural killer, or B cells. Within the T cell compartment, CD8+ effector memory cells were the predominant CAR-positive subset. Modest weight loss of 5.5 +/- $2.97 \%$ (mean +/- SD) observed in some animals receiving an anti-CD19CAR-GFP transgene during the protocol. These results indicate that direct IV infusion of lentiviral particles carrying an anti-CD19 CAR transgene can transduce T cells that then fully ablate endogenous B cells in wild type mice. Based on these results it may be useful to further explore, using currently available vectors, the feasibility of systemic gene therapy as a modality for CAR-T intervention.
\end{abstract}

Keywords: CAR-T, Immune effector cells; viral vector, gene transfer, gene therapy, leukemia, lymphoma

\section{Introduction}

Ordinarily, a cancer patient's immune system can recognize cancer cells as being altered, and mount a natural immune response. $\mathrm{T}$ cells are known to be the main mediators of the anti-cancer immune response but sometimes the natural $\mathrm{T}$ cell response is ineffective; $T$ cells may fail to recognize tumor cells, fail to activate, or fail to sustain a response long enough to have an impact. It is possible for these limitations to be overcome by genetic engineering strategies that involve isolating a sample of a patient's $\mathrm{T}$ lymphocytes, genetically modifying and activating the cells ex vivo, and then re-administering them to the same patient. The genetic modification step involves introducing into the $\mathrm{T}$ cells an extra gene that carries instructions for a new antigen receptor that may be a recombinant alpha-beta $\mathrm{T}$ cell receptor $(\alpha \beta T C R)$ or a Chimeric Antigen Receptor (CAR).

Currently, most genetically engineered Immune Effector Cell (IEC) therapies require several steps including i) manufacturing plasmid encoding the synthetic transgene and ancillary plasmids, ii) delivery of these plasmids into producer cells to generate virus, iii) collection of patient autologous $\mathrm{T}$ 
cells and integration of the transgene into the genomes of these cells by viral transduction, iv) expansion of the transduced T cells ex vivo to produce the therapeutic cells, v) extensive release testing of the manufactured product, vi) preconditioning lymphodepletion of the patient, vii) infusion of the modified autologous cells, and viii) intensive clinical and immunological monitoring. Thus, there is considerable infrastructure and expertise required to deliver IEC treatments safely and successfully. The complexity of manufacturing IECs is a critical limitation to the cell therapy field, and a major contributor to the high cost of reimbursement of new cell-based interventions coming to market.

Much of the growing interest in genetically engineered IECs as a new class of therapeutic is driven by the impressive results CAR-T therapies have shown in patients with relapsed/refractory B-cell Acute Lymphoblastic Leukemia or Non-Hodgkin Lymphoma. These patients, for whom standard therapies have failed, have historically had dismal outcomes with survival measured in weeks or months. Remarkably, CAR-T therapy targeting CD19 has led to meaningful and durable remissions for large proportion of these patients in many different studies[1-7].

Ideally, to reduce the logistical burden of IEC therapies, a master allogeneic cell bank would be manufactured centrally and distributed to clinical sites for infusion as a "universal" cell product. For this approach it would be necessary to source large numbers of primary, non-immortalized cells from allogeneic donors. Many donors would be needed because there is a limit to the number of cells that can be obtained per donor, resulting in non-homogeneous products susceptible to batch-to-batch variation. Of course, allogeneic therapies also face the fundamental limitations of susceptibility to graft rejection (caused by recognition of allo-antigens on donor cells by the recipient's endogenous $\mathrm{T}$ cells) and graft-versus-hostdisease (caused by systemic reactivity of donor cells to the recipient's allo-antigens). Despite these major hurdles to universal cell therapies, the manufacturing constraints associated with personalized autologous products are so severe that "AlloCAR-T" therapy has become an area of intense interest. To engineer universal IECs one approach has been to knockout the endogenous TCR in the T cell product to attenuate anti-host activity, and to delete receptors in the cell product for immunosuppressant drugs such as alemtuzumab (anti-CD52) to confer resistance, such that those drugs can then be administered to the recipient to selectively inhibit host immunity and prevent graft rejection, but not inhibit the function of the grafted allogeneic cells. Indeed some successes have been demonstrated in pre-clinical work [8] and in case studies[9,10] with gene-edited allo-CAR-Ts. Likewise, the immortalized IEC cell line NK-92 has shown encouraging safety and efficacy in a recent phase 1 trial, but the requirement of irradiating the cells pre-infusion to reduce oncogenic risk will likely remain limiting for this approach.[11] The generation of a bank of allogeneic CAR-T cells by in vitro differentiation and maturation of hematopoietic stem and progenitor cell precursors is an alternative and highly compelling strategy. Demonstrated in principle, this approach awaits further optimization.[12]

The best approach to universal IEC therapy may be to sidestep cell manufacturing entirely and infuse gene transfer vector directly in order to transduce $\mathrm{T}$ cells in vivo, redefining these treatments as gene therapies rather than cell therapies. The ability to safely administer gene transfer vectors directly, as is done for other modes of gene therapy[13-16] would be transformative for cancer immunotherapy.

In vivo gene delivery has previously been attempted, preclinically, for CAR-T therapy. Nanoparticles have been demonstrated to be able to carry a CAR transgene payload and transduce $\mathrm{CD} 3^{+}$ cells, but this required flanking piggyBAC sequences and expression of a transposase to enable persistent CAR expression [17] and resulted in modification of non- $T$ cells as well as $T$ cells. In other recent work lentivirus modified to specifically target $\mathrm{CD}^{+} \mathrm{T}$ cells was engineered and tested for transfer of CAR constructs in vivo. Although specificity and transduction efficiency were limited, sufficient CART cells were generated to eliminate Nalm-6 tumor cells in NSG mice transplaned with human PBMC $[18,19]$. Here, we describe results from our 
experiments to test in vivo transfer of a CAR transgene to murine $\mathrm{T}$ cells using a conventional lentiviral vector and wild-type mice.

\section{$\underline{\text { Results }}$}

During our early pre-clinical development of an anti-CD19 CAR intervention for B cell malignancies we explored how CAR-T cells behave in vitro in the context of antigen driven expansion. Using a standard $2^{\text {nd }}$ generation anti-CD19 CAR design[20] (EF1 $\alpha$ promoter, FMC63 scFv CD19 binding domain, $\mathrm{CD} 8 \alpha$ hinge and transmembrane domain, 4-1BB co-stimulatory domain, CD3z signaling domain and 2A-GFP tag) and standard VSV-G pseudotyped lentivector, we transduced healthy donor human Peripheral Blood Mononuclear Cells (PBMC) in vitro and cultured these for nine weeks. We observed that CAR-modified T-cells expand rapidly and selectively relative to GFP transduced $\mathrm{T}$ cells when stimulated with irradiated allogeneic PBMC as a source of CD19 antigen[Figure 1A]. Expanded CAR-T cells showed robust CD19-dependent target cell killing in vitro with $66.0+/-0.14 \%$; (mean +/- SD) target cell death at $1: 1$ effector:target ratio, $90.2+/-2.62 \%$ target cell death at 4:1 effector:target ratio, and $94.4+/-0.35 \%$ target cell death at 10:1 effector:target ratio [Figure 1B].

Our observation that $\mathrm{B}$ cells drive robust expansion of functional CD19 CAR-T cells in vitro, plus the recent reports on $\mathrm{T}$ cell modification in situ noted above[17,18] led us to explore in vivo transduction and expansion of CAR-T cells using a murine model system. We constructed a CAR where we changed the $\mathrm{scFv}$ binding domain from FMC63[21] (a monoclonal antibody raised against human CD19) to 1D3[22] (a monoclonal antibody raised against mouse CD19). To verify activity in vitro, $2.5 \times 10^{5}$ splenocytes from wildtype C57BL/6 mice were transduced with lentivirus encoding either the 1D3-CD19CAR-GFP (murine), FMC63CD19CAR-GFP (human) or GFP-only transgene, then stimulated with a further excess of irradiated autologous murine splenocytes as a source of murine CD19 antigen. We observed that murine T-cells modified with either of the CARs expanded rapidly and selectively. Specifically, for murine $\mathrm{T}$ cells modified with the human CAR, expansion was $8.8+/-$ 0.03 (mean +/- SD) fold at day 63 relative to GFP transduced $\mathrm{T}$ cells $(\mathrm{p}<0.001$ Tukey's multiple comparison test), and for murine $\mathrm{T}$ cells modified with the murine CAR expansion was $12.9+/-0.09$ fold at day 63, relative to GFP transduced T cells ( $\mathrm{p}<$ 0.001 Tukey's multiple comparison test). The murine control T cells transduced with GFP-only lentivirus showed limited yet detectable expansion, possibly been driven by the original CD3/CD28 activation prior to transduction [Figures $\mathbf{2 A}$ and $\mathbf{2 B}$ ]. All expanded murine CAR-T cells showed robust and selective killing of murine B cells in vitro. The 1D3CD19CAR-GFP modified murine T cells killed 24.8 $+/-1.69 \%$ (mean +/- SD) of murine B cells in the 5 hour co-culture and the FMC63-CD19CAR-GFP modified murine $\mathrm{T}$ cells killed $18.5+/-1.08 \%$ of murine B cells in the 5 hour co-culture [Figure 2C].

Interestingly, this result indicates that the FMC63 scFv is able to bind murine CD19, to the degree necessary for functional CAR-T activation in this experimental system. To our knowledge this has not previously been reported.

We then administered lentivirus encoding each CAR or GFP-only lentivirus to $\mathrm{C} 57 \mathrm{~B} / 6$ wild type mice (age 4-6 weeks) by tail vein infusion, and drew peripheral blood at regular intervals. We observed that GFP-expressing $\mathrm{T}$ cells appear in the blood of mice 3 weeks after the initial injection of $1.8-2 \times 10^{7}$ infectious units (IU) of either the 1D3- or FMC63-CD19CAR-GFP lentivirus, but not after injection of the same dose of GFP-only lentivirus [Figures 3A and 3B]. Specifically, we saw emergence of a persistent 1D3-CD19CAR-GFP transduced $\mathrm{CD}^{+} \mathrm{T}$ cell population beginning at week 3 that reaching a maximum of $13.5+/-0.58 \%$ (mean $+/-\mathrm{SD})$ of the peripheral blood $\mathrm{CD}^{+} \mathrm{T}$ cell population by week 5 [Figures $3 \mathrm{~A}$ and $4 \mathrm{~A}$ ]. This coincided with the loss of B cells, seen 5 weeks after the initial injection [Figures $\mathbf{3 A}$ and $4 B$ ]. In experiments where we infused murine $\mathrm{T}$ cells modified with the FMC63-CD19CAR-GFP construct we also saw the emergence of a persistent FMC63CD19CAR-GFP transduced $\mathrm{CD}^{+} \mathrm{T}$ cell population beginning at week 5 that reached a maximum of 7.8 
Rive et al., 21 NOV 2020 - preprint copy version 2 - BioRxiv

$+/-0.76 \%$ of the peripheral blood $\mathrm{CD}^{+} \mathrm{T}$ cell population by week 5 [Figures $3 \mathrm{~A}$ and 3B]. Again, this coincided with a loss of $\mathrm{B}$ cells, seen 5 weeks after the initial injection. This further confirms functional recognition of murine CD19 by FMC63 [Figures 3A and 4B]. With either CAR, B cell aplasia was sustained until the end of the protocol (week 8). Mice treated with 1.8-2 x10 ${ }^{7}$ IU of the GFP control lentivirus had no GFP expressing $\mathrm{T}$ cells and did not show the same B cell loss. We looked for GFP expression in immune cell subsets other than $\mathrm{T}$ cells, including the CD20/CD45R/B220 B cell population, $\mathrm{CD}_{11 b^{+}}$macrophage, and $\mathrm{CD} 335^{+}$natural killer (NK) cells, but found that only $\mathrm{T}$ cells expressed the reporter GFP gene, indicative of CAR expression, Our interpretation of these results is that interaction between the in vivo transduced CAR-T cells and endogenous B cells drives CAR-T cell expansion and CAR-T mediated $\mathrm{B}$ cell depletion, resulting eventually in B cell aplasia [Figure 4].

To further assess in vivo transduced CAR-T cells from peripheral blood we used a panel of markers that included CD3, CD4, CD8, CD44, CD62L and CD127 [Figure 5]. A gating strategy for the use of these markers to define $\mathrm{T}$ cell immunophenotypes has been previously described[23,24], and an example of our implementation is illustrated in Figure S6. At both timepoints tested (week 5 and week 8), we saw that $\mathrm{CD}^{+}$CAR-T cells were more prevalent than $\mathrm{CD}^{+}$ CAR-T cells, and displayed mainly effector $\left(\mathrm{CD} 44^{\text {high }}, \mathrm{CD}^{\mathrm{C}} \mathrm{L}^{\text {low }} \mathrm{CD} 127^{\text {low }}\right.$ ) or effector memory (CD44 ${ }^{\text {high }}$ CD62L ${ }^{\text {low }}$ CD127 ${ }^{\text {high }}$ ) phenotypes. Interestingly, these ID3 CAR-T cells proliferated sooner, and to a greater abundance than the FMC63 CAR-T cells, which didnot become prominent until week 8. A small $(<1 \%)$ but measurable population of GFP expressing $\mathrm{CD}^{+}{ }^{+} \mathrm{FOXP}^{+}{ }^{+}$regulator $\mathrm{T}$ cells was also observed at both timepoints.

The only overt change observed in mice treated with either 1D3- or FMC63-CD19CAR lentivirus was a modest decrease in weight of $5.5+/$ $2.97 \%$ (mean +/- SD) and 3.6 +/- 1.78\%, respectively over the first week after treatment [Figure S7].

\section{Discussion}

Here we report the observation that upon intravenous infusion, replication-incompetent lentiviral particles carrying an anti-CD19 CAR transgene can effectively transduce $T$ cells, leading to CAR-T proliferation and B cell aplasia. This supports the notion that CAR-T cells generated in this manner could be effective against B cell malignancies, with limited toxicity. If further testing indicates this is the case, then the potential of this protocol for "universal CAR-T therapy" warrants careful consideration. From our perspective there are many issues to explore when considering systemic gene therapy as an alternative to ex-vivo manufacturing of CAR-T cells, and these factors are inter-related:

\section{Efficiency and target cell specificity.}

For clinically relevant anti-tumor efficacy, a sufficient number of target $\mathrm{T}$ cells needs to be encountered by virus, successfully transduced, and reliably and persistently express the receptor transgene at physiologically relevant levels. Most lentiviral gene transfer vectors used clinically, including the vector we use here, are pseudotyped using vesicular stomatitis virus G glycoprotein (VSVG). VSV-G binds the LDL receptor expressed on the surface of most cell types including $\mathrm{T}$ cells. Upon intravenous (IV) injection of virus, $\mathrm{T}$ cells plus all other hematopoietic cells and vascular endothelial cells are susceptible to transduction. While successfully transduced $\mathrm{T}$ cells expressing a CAR may undergo antigen driven expansion in vivo, bystander cells that do not expand can still be problematic if they act as viral sinks. Thus, it will be necessary to define empirically the optimal viral dosing regimen. Further implications to the transduction of bystander cells are unique to the setting of anti-CD19 CAR-T therapy. For example, expression of the CAR transgene in malignant $\mathrm{B}$ cells by inadvertent transduction of tumor blasts is problematic, because the CAR can bind CD19 antigen on the same cell and block engagement by cytolytic CAR-T cells. This is a known but rare mechanism of relapse in conventional ex vivo protocols [25] and could be exacerbated by in vivo transduction. Another consideration is that while receptor transgene 
expression in $\mathrm{CD}^{+}$cytolytic $\mathrm{T}$ cells and $\mathrm{CD} 4^{+}$helper $\mathrm{T}$ cells is desirable,[26] expression in regulatory $\mathrm{T}$ cells, which we observe at a low level [Figure 5], may have a non-negligible inhibitory effect on CAR$\mathrm{T}$ cell immunoreactivity over time. Utilizing modified promoters that drive CAR transgene expression in effector but not regulatory $\mathrm{T}$ cells is one strategy for overcoming this potential problem.

Interestingly, murine $\mathrm{T}$ cells have previously been demonstrated to have lower transduction efficiencies, compared to human $\mathrm{T}$ cells and compared to other murine cell types[27-30], when transduced with HIV-1 based lentiviral vectors. The viral vector system we describe here avoids some of the known barriers of murine $\mathrm{T}$ cells. The entry block is avoided by the use of VSV-G pseudotyped virus. Reduced Tat activation is avoided entirely by our use of a Tat-independent transfer vector with a chimeric Rous Sarcoma virus LTR. Reduced LTR promoter activity is compensated by the use of an internal EF1 $\alpha$ promoter driving the transgene. Some reduction in lentiviral integration can still be expected in murine $\mathrm{T}$ cells due to inefficient nuclear import of the preintegration complex.[29] Empirically, however, we find that while our lentiviral vectors transduce murine $\mathrm{T}$ cells less efficiently than they transduce human $\mathrm{T}$ cells [Figures S2], the level of transduction of murine $\mathrm{T}$ cells in vitro and in vivo is sufficient for CAR-T generation.

It is also important to note that lymphocyte proportions in C57BL/6 mouse PBMC differ from lymphocyte proportions in human. Specifically, these mice exhibit a higher proportion of $B$ cells and a different CD4:CD8 $\mathrm{T}$ cell ratio than human. These differences have been noted in other studies, consistent with the proportions of $\mathrm{B}$ and $\mathrm{T}$ cells we observed in the present study. [31,32]

Immunogenicity.

A well-recognized issue that can limit the utility of systemic gene therapy is the inherent immunogenicity of viral gene transfer vectors. For example, pre-existing immunity to adenoviral vectors is common in the population due the high incidence of exposure to natural adenoviruses. Other viruses, such as Maloney Murine Leukemia Virus (MMLV) and adeno-associated viruses have limited pre- existing immunity but are immunogenic when used as gene transfer vectors. Pre-existing immunoreactivity to lentivirus is generally absent in the population, and acute immunoreactivity to infused CAR-bearing virus is mitigated by CAR-T mediated depletion of the B cell compartment including the potentially antilentiviral antibody producing B cells. These dynamics will be important to evaluate but we do not expect immunogenicity will be limiting given that IEC therapies are typically single dose administrations. It is already well established that patients who respond to CAR-T therapy do so after a single infusion, and that re-infusing a non-responsive patient does not provide significant benefit.[33]

\section{Safety.}

Insertional mutagenesis of integrating viral vectors led to highly regrettable negative outcomes in early gene therapy trials and severe setbacks to the gene therapy field.[34-39] All of these clinical trials involved ex-vivo gene transfer to hematopoietic stem cells using "first generation" gamma-retroviral vectors. Retrospective analysis has shown that the mechanism of leukemogenesis was oncogene overexpression driven by integration, in the vicinity of oncogenes, of viral vectors bearing strong promoters in their long terminal repeats. The advent of self-inactivating lentiviral vectors with transgene expression driven by mammalian not viral LTR promoters (as used in the present study) have mitigated oncogenic risk $[40,41]$ are now routinely used in different disease settings without incident and no detrimental effects of insertional mutagenesis have been reported from any CAR-T clinical trial using retroviral vectors to date. Still, for in vivo CAR-T transduction, the risk of insertional mutagenesis remains to be evaluated. Until then, any approaches that minimize transduction of off target cells may be of benefit.

The use of HIV-based lentivirus for gene transfer also raises concern about the theoretical risk of transmission of replication competent lentivirus (RCL). We use a modified $2^{\text {nd }}$ generation lentiviral vector system with the minimal viral components included in the $3^{\text {rd }}$ generation system split across three plasmids instead of four. These alterations abolish the 
potential for recombination events that can lead to formation of RCL in target cells. Testing of hundreds of cell therapy products generated with third generation vectors as well screening clinical trial participants after infusion of cell product failed to detect RCL, [42,43] demonstrating the safety of lentiviral gene therapy in this regard.

\section{Patient conditioning.}

CAR-T protocols and other clinical IEC protocols typically include lymphodepleting chemotherapy with cyclophosphamide and/or fludarabine as pre-conditioning. While it is not yet known exactly how this facilitates response, it is thought to improve engraftment by depleting endogenous $\mathrm{T}$ effector cells that compete for resources, and deplete regulatory $\mathrm{T}$ cells that may otherwise suppress the infused CAR-T population. While it would not be productive to perform complete lymphoablation prior to a viral infusion protocol (because endogenous $\mathrm{T}$ cells must be present for virus to transduce), mild preconditioning may be beneficial, such that depletion leaves enough endogenous $\mathrm{T}$ cells in circulation to support viral transduction and conversion to CAR-Ts, while at the same time providing space for robust CAR-T expansion and engraftment. This could be further tested, but may be unnecessary given our results show full ablation of endogenous B cells after lentiviral infusion [Figure 2] without any pre-conditioning lymphodepletion.

In summary, anti-CD19 CAR-T therapy for B cell malignancies has shown clinical success, but a major limitation is the logistical complexity and high cost of manufacturing autologous cell products. This has led to increasing interest in industry and academia in universal (non-personalized) strategies. Here we have shown that direct IV injection of lentiviral particles carrying the anti-CD19 CAR transgene can transduce $\mathrm{T}$ cells that then fully ablate endogenous B cells in wild type mice, indicating that direct infusion of viral gene transfer vectors to initiate in vivo $\mathrm{T}$ cell transduction, expansion and anti-tumor activity is a potential universal approach.

\section{Materials and Methods}

\section{Media}

RPMI-1640 supplemented media (sRPMI1640) consisted of $2 \mathrm{mM}$ GlutaMAX (Invitrogen, 35050-061), $1 \mathrm{mM}$ MEM non-essential amino acid (Invitrogen, 11140-050), $1 \mathrm{mM}$ sodium pyruvate (Invitrogen, 11360-070), 10 mM HEPES (Invitrogen, 15630-808), $100 \mathrm{U} / \mathrm{mL}$ penicillin- streptomycin (Invitrogen, 15140-122), MycoZap prophylactic (Lonza, VZA-2031), $\quad 0.05 \mathrm{mM}$ 2-Beta Mercaptoethanol (Sigma, 60-42-2, 2- $\beta$ ME added to media for murine cell cultures only) and $10 \%$ heatinactivated fetal bovine serum (Invitrogen, 12484028). For expansion cultures IL-2 (StemCell, 78036.3) was added to the sRPMI-1640 media. Cells were cultured in sRPMI-1640 with a final IL-2 concentration of $300 \mathrm{IU} / \mathrm{ml}$, unless otherwise stated.

FACS media consisted of 1x D-PBS (Sigma, 59331C) with $2 \%$ HI-FCS.

In house MACS separation buffer consisted of D-PBS with 2mM EDTA (ThermoFisher, 15575020) and $2 \% \mathrm{HI}-\mathrm{FBS}$.

Production of lentiviral gene transfer vectors. Our lentivector system is a modified $2^{\text {nd }}$ generation system that uses three separate plasmids to split the lentiviral genome as previously described.[44,45] The system is comprised of a packaging plasmid encoding gag, pol and rev, an envelope expressing plasmid and a transfer plasmid encoding the transgene. Biosafety of the $2^{\text {nd }}$ generation design was improved by removal of tat from the packaging plasmid with the concurrent replacement of the transfer vector 5' Long terminal repeat (LTR) with chimeric sequence for Tatindependent expression and a self-inactivating modified 3' LTR.[46] These modifications serve to prevent the formation of replication competent virus.

Synthetic transgene sequences encoding 1) GFP, 2) FMC63-CD19CAR-2A-GFP and 3) 1D3CD19CAR-2A-GFP were manufactured (ATUM), subcloned into the transfer plasmid and verified by sanger sequencing (Genewiz). To manufacture virus particles, envelope, packaging, and transfer plasmid were co-transfected into the packaging cell line HEK$293 \mathrm{~T}$ (clone 17; ATCC) using TransIT-LT1 (Mirus, MIR2305). Media containing the lentivirus was collected after transfection, filtered and then 
ultracentrifuged at $25,000 \mathrm{rpm}$ or $106,750 \mathrm{xg}$, for 90 minutes at $4^{\circ} \mathrm{C}$ (Optima XE-90, Beckman-Coulter with SW $32 \mathrm{Ti}$ swinging bucket rotor) to pellet the virus. Viral pellets were resuspended in $1 \mathrm{x}$ D-PBS and aliquoted for long term storage at -80C. Functional viral titers were established by infection of K562 cells (ATCC) and EL4 cells (ATCC) determined by transducing $5 \times 10^{4}$ EL4 or K562 cells (ATCC) with $1,2,4,8,16$, or $32 \mu \mathrm{L}$ of concentrated viral supernatant. Performed in duplicate, cells were suspended in a final volume of 500uL of sRPMI-1640 media, in the 24-well format. Cells were then incubated for 72 hours, before being washed, centrifuged, and resuspended in FACS media. Acquisition was performed on the BD LSRFortessa cell analyser, and analysed using FlowJo and GraphPad Prism software version 8.0.0 for windows (GraphPad Software, California, USA) [Figure S1 and Figure S2].

\section{Sample acquisition and storage.}

Human PBMCs were isolated by Ficoll gradient purification as per manufactures protocol (Ficoll, GE-17-1440, GE Healthcare) from human peripheral blood leukapheresis pack (StemCell). 100$150 \mu 1$ of $\mathrm{C} 57 \mathrm{BL} / 6$ mouse blood was collected in lithium heparin capillary tubes via tail vein blood sampling pre-treatment and then every week posttreatment for 8 weeks. The blood samples were diluted with $1-1.5 \mathrm{ml}$ of cold RPMI, which was overlayed with $4 \mathrm{ml}$ of Ficoll and C57BL/6 mouse PBMCs were isolated following the manufacturer's protocol. C57BL/6 mouse PBMCs were isolated and analysed within 24 hours of isolation. PBMCs were resuspended in sRPMI-1640 at a concentration of $1 \times 10^{6}$ cells per ml, placed into a T25 culture flask (156367, ThermoFisher), and rested overnight in the cell incubator at $37^{\circ} \mathrm{C}$ with $5 \% \mathrm{CO}_{2}$ airflow before being used in any analysis. Human PBMCs and C57BL/6 mouse PBMCs not immediately used in any experiments were stored down by resuspending cells in freezing media (HI-FBS with 10\% DMSO, Fisher Scientific, BP231-100) in aliquots of $5-10 \times 10^{6}$ cells per $\mathrm{ml}$ and frozen down to $-80^{\circ} \mathrm{C}$ at a speed of $1{ }^{\circ} \mathrm{C} / \mathrm{min}$ prior to storage in liquid nitrogen.

The C57BL/6 mouse splenocytes used in the in vitro assays were acquired from naive or untreated C57BL/6 mice, aged 4-8 weeks old. All C57BL/6 mice were however processed the same way by first manually dissociating the spleens and filtering them through a $70 \mu \mathrm{m}$ cell strainer (Corning, CLS431751) into a $50 \mathrm{~mL}$ falcon tube, centrifuging $400 \mathrm{xg}$ for 10 min (Eppendorf Centrifuge 5810R, rotor A-4-62) at room temperature to pellet the cells. The splenocytes samples were resuspended in $5 \mathrm{~mL}$ of ACK (Ammonium-Chloride-Potassium) Lysing Buffer (ThermoFisher), before incubating the cells on ice for no longer than 4 minutes. $10 \mathrm{~mL}$ of sRPMI-1640 media was added to the cells to neutralize the ACK buffer and wash the splenocytes. The splenocytes were then centrifuged at 400xg for $10 \mathrm{~min}$ (Eppendorf Centrifuge 5810R, rotor A-4-62) at room temperature, the supernatant was removed, and the splenocytes washed again before being resuspended in sRPMI1640 media and cell numbers obtained using the Countess automated cell counter (ThermoFisher). 
Splenocytes were stored down by resuspending cells in freezing media (HI-FBS with 10\% DMSO, Fisher Scientific, BP231-100) in aliquots of $5-10 \times 10^{6}$ cells per $\mathrm{ml}$ and frozen down to $-80^{\circ} \mathrm{C}$ at a speed of $1^{\circ} \mathrm{C} / \mathrm{min}$ prior to storage in liquid nitrogen.
In vitro FMC63-CD19CAR-GFP modified T cell expansion and testing using human PBMCs.

$5 \times 10^{5}$ Human PBMCs were rested in RPMI1640 supplemented media at $1 \times 10^{6}$ cells $/ \mathrm{mL}$ with $300 \mathrm{IU} / \mathrm{ml}$ of IL-2 for 24 hours and then transduced at a MOI of 5 (calculated based on titration data) with either FMC63- or GFP lentivirus. Transduced cells were then incubated for 48 hours before cells were washed with RPMI-1640 supplemented media, centrifuged at $300 \mathrm{x} \mathrm{g}$ for $5 \mathrm{mins}$ at room temperature (Eppendorf centrifuge 5810R) and resuspended in RPMI-1640 supplemented media with $300 \mathrm{IU} / \mathrm{ml}$ of IL-2 and $5 \times 10^{7}$ irradiated allogeneic PBMCs (50Gy). Cells were cultured with $50 \%$ of the media being removed and replaced with fresh media every third day, or split to maintain cells at $1 \times 10^{6}$ cells $/ \mathrm{mL}$. Cells were counted using a Countess automated cell counter (ThermoFisher), and aggregate counts were determined on day 24 and 63[Figure 1A].

To assess the cytolytic activity of FMC63CD19CAR-GFP, $1 \times 10^{5}$ cells expanded from transduced human PBMCs (effectors) were labelled with cell proliferation dye eFluor 450 (eBiosciences) and co-cultured with sRPMI-1640 in $5 \mathrm{~mL}$ Falcon round-bottom polystyrene tubes (Fisher) for 4 hours with $\mathrm{CD}^{+} 9^{+} 721.221$ (ATCC) or $\mathrm{CD}^{-} 9^{-} \mathrm{K} 562$ (ATCC) cells (targets) using $1 \times 10^{5}(1: 1), 4 \times 10^{5}(4: 1)$ or $1 \times 10^{6}(10: 1)$ target cells [Figure 1B]. Prior to the co-culture, the target cells (721.211 and K562 cells) were stained with the cell proliferation dye eFluor 670 (eBiosciences). At the end of the co-cultures, the cells were stained with DAPI (ThermoFisher). Flow cytometry data acquisition was performed using the BD LSRFortessa cell analyser with BD FACSDiva software and the analysis was performed using FlowJo software, version 10 for Windows GraphPad Prism software version 8.0.0 for windows (GraphPad Software, California, USA) [Figure S3].

In vitro 1D3- and FMC63-CD19CAR-GFP modified $T$ cell expansion and testing using $C 57 B L / 6$ mouse splenocytes

C57BL/6 mouse splenocytes were removed from liquid nitrogen storage, thawed, and resuspended in sRPMI-1640 with $300 \mathrm{IU} / \mathrm{ml}$ of IL-2, and 30ng/ml of CD3 (clone 145-2C11, 100314, BioLegend) and 30ng/ml CD28 (clone 37.51, 102112, 
BioLegend) antibodies, at a concentration of $1 \times 10^{6}$ cells $/ \mathrm{ml}$. The splenocytes were then treated with 1D3-

FMC63-CD19CAR-GFP, or GFP-only viral supernatant at a MOI of 5 (calculated based on titration data) and incubated for 72 hours. Following transduction, cells were washed by resuspending the cells in sRPMI-1640, centrifuging them at 400xg for 10 mins at room temperature (Eppendorf Centrifuge 5810R, rotor A-4-62), removing the supernatant, and repeating the process a further 2 times. The cells were resuspended in sRPMI-1640 media containing $300 \mathrm{IU} / \mathrm{ml}$ of IL-2 at a concentration of $2.5 \times 10^{5}$ cells per $\mathrm{ml}$, with $1 \mathrm{ml}$ being aliquoted per well, in the 6well culture plate format. Irradiated autologous murine splenocytes (50Gy) were resuspended in sRPMI-1640 media containing 300IU/ml of IL-2 at a concentration of $2.5 \times 10^{7} / \mathrm{ml}$ and $1 \mathrm{ml}$ was added to the transduced splenocytes giving a final ratio of 1:100 transduced splenocytes to irradiated splenocytes. Every third day, $1 \mathrm{ml}$ of the culture media was removed and $1 \mathrm{ml}$ of fresh sRPMI-1640 media with $600 \mathrm{IU} / \mathrm{ml}$ of IL-2 was added (giving a final concentration of $300 \mathrm{IU} / \mathrm{ml} \mathrm{IL}-2$ ). On days $0,14,28$, and 63 , the cells were counted using the Countess automated cell counter (ThermoFisher) and an aliquot of $3 \times 10^{4}$ cells were stained with fluorescent labeled antibodies and analyzed using flow cytometry [Figure 2A and Figure 2B].

In a 96-well plate format with a final volume of $200 \mu 1$ (sRPMI-1640), $1 \times 10^{5}$ 1D3-, FMC63CD19CAR, or GFP-transduced T cells from day 63 of the expansion were co-cultured for 5 hours with $1 \times 10^{5} \mathrm{~B}$ cells isolated from another sample of C57BL/6 mouse splenocytes, using the Miltenyi MACS mouse CD19 B-cell isolation beads, following the manufacturer's protocol and using a MACS separation buffer made in-house. At the end of the coculture, the cells were stained with fluorescent labeled antibodies and analyzed using flow cytometry [Figure 2C]. Cells were washed with $500 \mu$ l of DPBS and centrifuged at $400 \mathrm{xg}$ for 10 minutes at room temperature (Eppendorf Centrifuge 5810R, rotor A-462 ). The supernatant was removed and the cell pellet resuspended in $50 \mu 1$ of D-PBS before being stained with CD20-PE (clone A1SB12, 12-0201-82, eBioscience), CD3-efluor 450 (clone 17A2, 48-0032-
82, eBioscience), and the non-viable cell marker, Fixable Viability Stain 780 (FVS780) (565388, BD Biosciences). Cells and antibodies were incubated at $4^{\circ} \mathrm{C}$ for $30 \mathrm{~min}$, then washed by adding $2 \mathrm{~mL}$ of FACS media to each tube and centrifuging for 10 minutes at $400 \mathrm{xg}$ at $4^{\circ} \mathrm{C}$ followed by removal of the supernatant before resuspension in $500 \mu$ of cold FACS media. Flow cytometry acquisition was performed using the BD LSRFortessa cell analyser with BD FACSDiva software. The analysis was performed using FlowJo software, version 10 for windows and GraphPad Prism software version 8.0.0 for windows (GraphPad Software, California, USA) [Figure S4].

\section{In vivo testing.}

All animal experiments were assessed and approved by the University of British Columbia's Animal Care Committee under ethics certificate \#A17-0107. For the in vivo testing, male C57BL/6 mice, aged 4 to 6 weeks old, were obtained from the BC Cancer Research Centre's Animal Resource Centre. The experimental mice received one tail vein infusion on day 1 which involved the injection of $200 \mu 1$ of D-PBS containing $1.8-2 \times 10^{7}$ total infectious units of either 1D3-, FMC63-CD19CAR-GFP, or GFP-only lentiviruses. Mice were monitored closely for the first 72 hours, and then once a day until the experimental endpoint. The mice were also weighed periodically and blood collected in lithium heparin capillary tubes via tail vein sampling as previously described. At the experimental endpoint, the mice were humanly euthanized and spleen and blood tissue collected and processed as previously described. The cells were stained with fluorescent labeled antibodies and analyzed using flow cytometry [Figure $\mathbf{3}$ and Figure 4]

For flow cytometry acquisition and analysis, $1 \times 10^{5}$ cells were stained with CD3-efluor 450 (clone 17A2, 48-0032-82, eBioscience), CD90.2-AF700 (clone 30-H12, 105319, BioLegend), CD20-PE (clone A1SB12, 12-0201-82, eBioscience), CD45R/B220APC-CY7 (clone RA3-6B2, 103223, BioLegend), CD335-APC (clone 29A1.4, 137608, BioLegend), and CD11B-BV605 (clone M1/79, 101237, BioLegend) conjugated flow antibodies. Cells and antibodies were incubated at $4^{\circ} \mathrm{C}$ for $30 \mathrm{~min}$, then washed by adding $2 \mathrm{~mL}$ of FACS media to each tube 
and centrifuging for 10 minutes at $400 \mathrm{xg}$ at $4^{\circ} \mathrm{C}$, discarding the supernatant before resuspension in $500 \mu \mathrm{l}$ of cold FACS media. Acquisition was performed on the BD LSRFortessa cell analyser, and analysed using FlowJo and GraphPad Prism software version 8.0.0 for windows (GraphPad Software, California, USA) [Figure S5].

In the immunophenotyping analysis, up to $1 \times 10^{5}$ cells were stained with CD3-efluor 450 (clone 17A2, 48-0032-82, eBioscience), CD4-PE (clone GK1.5, 100408, BioLegend), CD8-BUV395 (clone QA17A07, 155006, BioLegend), CD44-alexa fluor 700 (clone IM7, 103026, BioLegend), CD62L-PerCPCY5.5 (clone MEL-14, 104432, BioLegend), CD127APC-CY7 (clone A7R34, 135040, BioLegend), CD25-PE-CF594 (clone PC61, 562694, BD Biosciences), and FOXP3-APC (clone FJK-16s, 563786, BD Biosciences) and incubated at $4^{\circ} \mathrm{C}$ for 30 min, as previously mentioned. The cells were then fixed, by incubating the cells in up to $200 \mu \mathrm{L}$ of fixation buffer (420801, BioLegend) at $4^{\circ} \mathrm{C}$ for 30 min. The cells were than washed by adding $2 \mathrm{~mL}$ of FACS media and centrifuging for 10 minutes at $400 \mathrm{xg}$ at $4^{\circ} \mathrm{C}$, and resuspended in $1 \mathrm{x}$ Intracellular Staining Perm Wash Buffer (10x stock solution, diluted to $1 \mathrm{x}$ with $\mathrm{ddH}_{2} \mathrm{O}, 420801$, BioLegend) at $4^{\circ} \mathrm{C}$ for $30 \mathrm{~min}$, before being stained with FOXP3-APC (at $4^{\circ} \mathrm{C}$ for $30 \mathrm{~min}$ ). Again cells were washed by adding $2 \mathrm{~mL}$ of FACS media and centrifuging for 10 minutes at $400 \mathrm{xg}$ at $4^{\circ} \mathrm{C}$, discarding the supernatant before resuspension in $500 \mu \mathrm{l}$ of cold FACS media. Acquisition was performed on the BD LSRFortessa cell analyser, and analysed using FlowJo and GraphPad Prism software version 8.0.0 for windows (GraphPad Software, California, USA) [Figure S6].

For all flow analyses, we used the CD20-PE antibody as a B cell marker in place of a CD19 antibody (Figure 2, Figure 3, Figure 4) to avoid any possible interference between anti-CD19 antibody and anti-CD19 CARs in these mixed cell populations.

\section{Author Contributions and Notes}

R.A.H, C.M.R and E.Y. designed research, C.M.R, E.Y, L.D., and D.J.W. performed research, C.M.R analyzed data; all authors prepared and edited the manuscript.
The authors declare no conflict of interest.

\section{Acknowledgments}

This research was supported by the British Columbia Cancer Foundation, the Leon Judah Blackmore Foundation and the BioCanRx network. 
bioRxiv preprint doi: https://doi.org/10.1101/2020.05.15.098335; this version posted November 23, 2020. The copyright holder for this preprint

(which was not certified by peer review) is the author/funder, who has granted bioRxiv a license to display the preprint in perpetuity. It is made available under aCC-BY-NC-ND 4.0 International license.

Rive et al., 21 NOV 2020 - preprint copy version 2 - BioRxiv

\section{References}

1. Neelapu SS, Locke FL, Bartlett NL, Lekakis LJ, Miklos DB, Jacobson CA, Braunschweig I, Oluwole OO, Siddiqi T, Lin Y, Timmerman JM, Stiff PJ, Friedberg JW, Flinn IW, Goy A, Hill BT, Smith MR, Deol A, Farooq U, McSweeney P, Munoz J, Avivi I, Castro JE, Westin JR, Chavez JC, Ghobadi A, Komanduri K V., Levy R, Jacobsen ED, Witzig TE, Reagan P, Bot A, Rossi J, Navale L, Jiang Y, Aycock J, Elias M, Chang D, Wiezorek J, Go WY. Axicabtagene ciloleucel CAR T-cell therapy in refractory large B-Cell lymphoma. N Engl J Med. 2017 Dec 28;377(26):2531-44.

2. Maude SL, Laetsch TW, Buechner J, Rives S, Boyer M, Bittencourt H, Bader P, Verneris MR, Stefanski HE, Myers GD, Qayed M, De Moerloose B, Hiramatsu H, Schlis K, Davis KL, Martin PL, Nemecek ER, Yanik GA, Peters C, Baruchel A, Boissel N, Mechinaud F, Balduzzi A, Krueger J, June CH, Levine BL, Wood P, Taran T, Leung M, Mueller KT, Zhang Y, Sen K, Lebwohl D, Pulsipher MA, Grupp SA. Tisagenlecleucel in children and young adults with B-cell lymphoblastic leukemia. N Engl J Med. 2018 Feb 1;378(5):439-48.

3. Park JH, Rivière I, Gonen M, Wang X, Sénéchal B, Curran KJ, Sauter C, Wang Y, Santomasso B, Mead E, Roshal M, Maslak P, Davila M, Brentjens RJ, Sadelain M. Long-term follow-up of CD19 CAR therapy in acute lymphoblastic leukemia. $\mathrm{N}$ Engl J Med. 2018 Feb 1;378(5):449-59.

4. Hay KA, Gauthier J, Hirayama A V., Voutsinas JM, Wu Q, Li D, Gooley TA, Cherian S, Chen X, Pender BS, Hawkins RM, Vakil A, Steinmetz RN, Schoch G, Chapuis AG, Till BG, Kiem HP, Ramos JD, Shadman M, Cassaday RD, Acharya UH, Riddell SR, Maloney DG, Turtle CJ. Factors associated with durable EFS in adult B-cell ALL patients achieving MRD-negative CR after CD19 CAR T-cell therapy. Blood. 2019 Apr 11;133(15):1652-63.

5. Hirayama A V, Gauthier J, Hay KA, Voutsinas JM, Wu Q, Pender BS, Hawkins RM, Vakil A, Steinmetz RN, Riddell SR, Maloney DG, Turtle CJ. High rate of durable complete remission in follicular lymphoma after CD19 CAR-T cell immunotherapy. Blood [Internet]. 2019 Aug 15 [cited 2020 Apr 21];134(7):636-40. Available from: http://www.ncbi.nlm.nih.gov/pubmed/31648294

6. Schuster SJ, Svoboda J, Chong EA, Nasta SD, Mato AR, Anak Ö, Brogdon JL, Pruteanu-Malinici I, Bhoj V, Landsburg D, Wasik M, Levine BL, Lacey SF, Melenhorst JJ, Porter DL, June $\mathrm{CH}$. Chimeric antigen receptor $\mathrm{T}$ Cells in refractory BCell lymphomas. N Engl J Med. 2017 Dec 28;377(26):254554.

7. Grigor EJM, Fergusson D, Kekre N, Montroy J, Atkins H, Seftel MD, Daugaard M, Presseau J, Thavorn K, Hutton B, Holt RA, Lalu MM. Risks and Benefits of Chimeric Antigen Receptor T-Cell (CAR-T) Therapy in Cancer: A Systematic Review and Meta-Analysis. Vol. 33, Transfusion Medicine Reviews. W.B. Saunders; 2019. p. 98-110.

8. Sommer C, Boldajipour B, Kuo TC, Bentley T, Sutton J, Chen A, Geng T, Dong H, Galetto R, Valton J, Pertel T, Juillerat A, Gariboldi A, Pascua E, Brown C, Chin SM, Sai T, Ni Y, Duchateau P, Smith J, Rajpal A, Van Blarcom T, ChaparroRiggers J, Sasu BJ. Preclinical Evaluation of Allogeneic CAR $\mathrm{T}$ Cells Targeting BCMA for the Treatment of Multiple Myeloma. Mol Ther [Internet]. 2019 Jun 5 [cited 2020 Apr 22];27(6):1126-38. Available from: http://www.ncbi.nlm.nih.gov/pubmed/31005597

9. Qasim W, Zhan H, Samarasinghe S, Adams S, Amrolia P, Stafford S, Butler K, Rivat C, Wright G, Somana K, Ghorashian S, Pinner D, Ahsan G, Gilmour K, Lucchini G, Inglott S, Mifsud W, Chiesa R, Peggs KS, Chan L, Farzeneh F, Thrasher AJ, Vora A, Pule M, Veys P. Molecular remission of infant B-ALL after infusion of universal TALEN gene-edited CAR T cells. Sci Transl Med [Internet]. 2017 Jan 25 [cited 2020 Apr 22];9(374). Available from: http://www.ncbi.nlm.nih.gov/pubmed/28123068

10. Brudno JN, Somerville RPT, Shi V, Rose JJ, Halverson DC, Fowler DH, Gea-Banacloche JC, Pavletic SZ, Hickstein DD, Lu TL, Feldman SA, Iwamoto AT, Kurlander R, Maric I, Goy A, Hansen BG, Wilder JS, Blacklock-Schuver B, Hakim FT, Rosenberg SA, Gress RE, Kochenderfer JN. Allogeneic T Cells That Express an Anti-CD19 Chimeric Antigen Receptor Induce Remissions of B-Cell Malignancies That Progress After Allogeneic Hematopoietic Stem-Cell Transplantation Without Causing Graft-Versus-Host Disease. J Clin Oncol [Internet]. 2016 Apr 1 [cited 2020 Apr 22];34(10):1112-21. Available from: http://www.ncbi.nlm.nih.gov/pubmed/26811520

11. Williams BA, Law AD, Routy B, DenHollander N, Gupta V, Wang X-H, Chaboureau A, Viswanathan S, Keating A. A phase I trial of NK-92 cells for refractory hematological malignancies relapsing after autologous hematopoietic cell transplantation shows safety and evidence of efficacy. Oncotarget [Internet]. 2017 Oct 24;8(51):89256-68. Available from: http://www.ncbi.nlm.nih.gov/pubmed/29179517

12. Shukla S, Langley MA, Singh J, Edgar JM, Mohtashami M, Zúñiga-Pflücker JC, Zandstra PW. Progenitor T-cell differentiation from hematopoietic stem cells using Delta-like4 and VCAM-1. Nat Methods. 2017 Apr 27;14(5):531-8.

13. Dunbar CE, High KA, Joung JK, Kohn DB, Ozawa K, Sadelain M. Gene therapy comes of age. Science [Internet]. 2018 Jan 12 [cited 2020 Apr 22];359(6372):eaan4672. Available

from: http://www.ncbi.nlm.nih.gov/pubmed/29326244

14. Rangarajan S, Walsh L, Lester W, Perry D, Madan B, Laffan $\mathrm{M}, \mathrm{Yu} \mathrm{H}$, Vettermann C, Pierce GF, Wong WY, Pasi KJ. AAV5-Factor VIII Gene Transfer in Severe Hemophilia A. N Engl J Med [Internet]. 2017 Dec 28 [cited 2020 Apr 22];377(26):2519-30. Available from: http://www.ncbi.nlm.nih.gov/pubmed/29224506

15. Russell S, Bennett J, Wellman JA, Chung DC, Yu Z-FF, Tillman A, Wittes J, Pappas J, Elci O, McCague S, Cross D, Marshall KA, Walshire J, Kehoe TL, Reichert H, Davis M, Raffini L, George LA, Hudson FP, Dingfield L, Zhu X, Haller JA, Sohn EH, Mahajan VB, Pfeifer W, Weckmann M, Johnson C, Gewaily D, Drack A, Stone E, Wachtel K, Simonelli F, Leroy BP, Wright JF, High KA, Maguire AM. Efficacy and safety of voretigene neparvovec (AAV2-hRPE65v2) in patients with RPE65-mediated inherited retinal dystrophy: a randomised, controlled, open-label, phase 3 trial. Lancet (London, England) [Internet]. 2017 Aug 26 [cited $2020 \mathrm{Apr}$ 22];390(10097):849-60. Available from: http://www.ncbi.nlm.nih.gov/pubmed/28712537

16. Christine CW, Starr PA, Larson PS, Eberling JL, Jagust WJ, Hawkins RA, VanBrocklin HF, Wright JF, Bankiewicz KS, Aminoff MJ. Safety and tolerability of putaminal AADC gene therapy for Parkinson disease. Neurology [Internet]. 2009 Nov 17 [cited 2020 May 4];73(20):1662-9. Available from: http://www.ncbi.nlm.nih.gov/pubmed/19828868 
17. Smith TT, Stephan SB, Moffett HF, McKnight LE, Ji W, Reiman D, Bonagofski E, Wohlfahrt ME, Pillai SPSS, Stephan MT. In situ programming of leukaemia-specific T cells using synthetic DNA nanocarriers. Nat Nanotechnol [Internet]. 2017 Apr 17 [cited 2020 Apr 22];12(8):813-20. Available from: http://www.ncbi.nlm.nih.gov/pubmed/28416815

18. Pfeiffer A, Thalheimer FB, Hartmann S, Frank AM, Bender RR, Danisch S, Costa C, Wels WS, Modlich U, Stripecke R, Verhoeyen E, Buchholz CJ. In vivo generation of human CD $19 \square$ CAR $T$ cells results in $\mathrm{B} \square$ cell depletion and signs of cytokine release syndrome. EMBO Mol Med. 2018 Nov;10(11).

19. Agarwal S, Weidner T, Thalheimer FB, Buchholz CJ. In vivo generated human CAR $\mathrm{T}$ cells eradicate tumor cells. Oncoimmunology [Internet]. 2019;8(12):e1671761. Available from: http://www.ncbi.nlm.nih.gov/pubmed/31741773

20. Imai C, Mihara K, Andreansky M, Nicholson IC, Pui C-HH, Geiger TL, Campana D. Chimeric receptors with 4-1BB signaling capacity provoke potent cytotoxicity against acute lymphoblastic leukemia. Leukemia [Internet]. 2004 Apr [cited 2020 May 4];18(4):676-84. Available from: http://www.ncbi.nlm.nih.gov/pubmed/14961035

21. Nicholson IC, Lenton KA, Little DJ, Decorso T, Lee FT, Scott AM, Zola H, Hohmann AW. Construction and characterisation of a functional CD19 specific single chain Fv fragment for immunotherapy of B lineage leukaemia and lymphoma. Mol Immunol [Internet]. 1997 Nov 1 [cited 2020 May 5];34(1617):1157-65. Available from: http://www.ncbi.nlm.nih.gov/pubmed/9566763

22. Kochenderfer JN, Yu Z, Frasheri D, Restifo NP, Rosenberg SA. Adoptive transfer of syngeneic $T$ cells transduced with a chimeric antigen receptor that recognizes murine CD19 can eradicate lymphoma and normal B cells. Blood [Internet]. 2010 Nov 11 [cited 2020 Apr 22];116(19):3875-86. Available from: http://www.ncbi.nlm.nih.gov/pubmed/20631379

23. Huster KM, Koffler M, Stemberger C, Schiemann M, Wagner $\mathrm{H}$, Busch DH. Unidirectional development of CD8+ central memory $\mathrm{T}$ cells into protective Listeria-specific effector memory $\mathrm{T}$ cells. Eur J Immunol [Internet]. 2006 Jun;36(6):1453-64. Available from: http://www.ncbi.nlm.nih.gov/pubmed/16637009

24. Bachmann MF, Wolint P, Schwarz K, Jäger P, Oxenius A. Functional properties and lineage relationship of CD8+ T cell subsets identified by expression of IL-7 receptor alpha and CD62L. J Immunol [Internet]. 2005 Oct 1;175(7):4686-96. Available from: http://www.ncbi.nlm.nih.gov/pubmed/16177116

25. Ruella M, Xu J, Barrett DM, Fraietta JA, Reich TJ, Ambrose DE, Klichinsky M, Shestova O, Patel PR, Kulikovskaya I, Nazimuddin F, Bhoj VG, Orlando EJ, Fry TJ, Bitter H, Maude SL, Levine BL, Nobles CL, Bushman FD, Young RM, Scholler J, Gill SI, June CH, Grupp SA, Lacey SF, Melenhorst $\mathrm{JJ}$. Induction of resistance to chimeric antigen receptor $\mathrm{T}$ cell therapy by transduction of a single leukemic B cell. Nat Med [Internet]. 2018 Oct 1 [cited 2020 Apr 22];24(10):1499-503. Available http://www.ncbi.nlm.nih.gov/pubmed/30275568

26. Turtle CJ, Hanafi L-AA, Berger C, Gooley TA, Cherian S, Hudecek M, Sommermeyer D, Melville K, Pender B, Budiarto TM, Robinson E, Steevens NN, Chaney C, Soma L, Chen X, Yeung C, Wood B, Li D, Cao J, Heimfeld S, Jensen MC, Riddell SR, Maloney DG. CD19 CAR-T cells of defined
CD4+:CD8+ composition in adult B cell ALL patients. J Clin Invest [Internet]. 2016 Jun 1 [cited 2020 Apr 22];126(6):2123$38 . \quad$ Available from: http://www.ncbi.nlm.nih.gov/pubmed/27111235

27. Baumann JG, Unutmaz D, Miller MD, Breun SKJ, Grill SM, Mirro J, Littman DR, Rein A, KewalRamani VN. Murine T Cells Potently Restrict Human Immunodeficiency Virus Infection. J Virol. 2004 Nov 15;78(22):12537-47.

28. Kerkar SP, Sanchez-Perez L, Yang S, Borman Z a, Muranski P, Ji Y, Chinnasamy D, Kaiser ADM, Hinrichs CS, Klebanoff $\mathrm{C}$ a, Scott CD, Gattinoni L, Morgan $\mathrm{R}$ a, Rosenberg $\mathrm{S}$ a, Restifo NP. GeneticKerkar, S. P., Sanchez-Perez, L., Yang, S., Borman, Z. a, Muranski, P., Ji, Y., ... Restifo, N. P. (2011). Genetic engineering of murine CD8+ and CD4+ $\mathrm{T}$ cells for preclinical adoptive immunotherapy studies. Journal of Immunotherapy (Hagerstown, Md. $\square$ : J Immunother [Internet]. 2011 May [cited 2020 May 4];34(4):343-52. Available from: http://www.ncbi.nlm.nih.gov/pubmed/21499127

29. Tsurutani N, Yasuda J, Yamamoto N, Choi B-I, Kadoki M, Iwakura Y. Nuclear Import of the Preintegration Complex Is Blocked upon Infection by Human Immunodeficiency Virus Type 1 in Mouse Cells. J Virol. 2007 Jan 15;81(2):677-88.

30. Delville M, Soheili T, Bellier F, Durand A, Denis A, LagreslePeyrou C, Cavazzana M, Andre-Schmutz I, Six E. A Nontoxic Transduction Enhancer Enables Highly Efficient Lentiviral Transduction of Primary Murine T Cells and Hematopoietic Stem Cells. Mol Ther - Methods Clin Dev. 2018 Sep 21;10:341-7.

31. Pinchuk LM, Filipov NM. Differential effects of age on circulating and splenic leukocyte populations in C57BL/6 and $\mathrm{BALB} / \mathrm{c}$ male mice. Immun Ageing [Internet]. $2008 \mathrm{Feb}$ 11;5:1. Available from: http://www.ncbi.nlm.nih.gov/pubmed/18267021

32. Ridge K, Downes N, Finney B. Effects of strain, sex and age on immunophenotyping parameters in the rat and mouse. Comp Clin Path [Internet]. 2019 Feb 13;28(1):41-51. Available from: http://link.springer.com/10.1007/s00580-0182713-6

33. Bezerra E, Gauthier J, Hirayama A V. Factors associated with response, CAR-T cell in vivo expansion, and progression-free survival after repeat infusions of CD19 CAR-T cells. Present 61st Am Soc Hematol Annu Meet Expo Orlando, FL December 7-10, 2019. 2019;

34. Braun CJ, Boztug K, Paruzynski A, Witzel M, Schwarzer A, Rothe M, Modlich U, Beier R, Göhring G, Steinemann D, Fronza R, Ball CR, Haemmerle R, Naundorf S, Kühlcke K, Rose M, Fraser C, Mathias L, Ferrari R, Abboud MR, Al-Herz W, Kondratenko I, Maródi L, Glimm H, Schlegelberger B, Schambach A, Albert MH, Schmidt M, von Kalle C, Klein C. Gene therapy for Wiskott-Aldrich syndrome--long-term efficacy and genotoxicity. Sci Transl Med [Internet]. 2014 Mar 12;6(227):227ra33 Available from: http://www.ncbi.nlm.nih.gov/pubmed/24622513

35. Hacein-Bey-Abina S, Garrigue A, Wang GP, Soulier J, Lim A, Morillon E, Clappier E, Caccavelli L, Delabesse E, Beldjord K, Asnafi V, MacIntyre E, Dal Cortivo L, Radford I, Brousse N, Sigaux F, Moshous D, Hauer J, Borkhardt A, Belohradsky BH, Wintergerst U, Velez MC, Leiva L, Sorensen R, Wulffraat N, Blanche S, Bushman FD, Fischer A, Cavazzana-Calvo M. Insertional oncogenesis in 4 patients after retrovirus-mediated gene therapy of SCID-X1. J Clin Invest [Internet]. 2008 Sep;118(9):3132-42. Available from: 
http://www.ncbi.nlm.nih.gov/pubmed/18688285

Howe SJ, Mansour MR, Schwarzwaelder K, Bartholomae C, Hubank M, Kempski H, Brugman MH, Pike-Overzet K, Chatters SJ, de Ridder D, Gilmour KC, Adams S, Thornhill SI, Parsley KL, Staal FJT, Gale RE, Linch DC, Bayford J, Brown L, Quaye M, Kinnon C, Ancliff P, Webb DK, Schmidt M, von Kalle C, Gaspar HB, Thrasher AJ. Insertional mutagenesis combined with acquired somatic mutations causes leukemogenesis following gene therapy of SCID-X1 patients. J Clin Invest [Internet]. 2008 Sep;118(9):3143-50. Available from: http://www.ncbi.nlm.nih.gov/pubmed/18688286

37. Ott MG, Schmidt M, Schwarzwaelder K, Stein S, Siler U, Koehl U, Glimm H, Kühlcke K, Schilz A, Kunkel H, Naundorf S, Brinkmann A, Deichmann A, Fischer M, Ball C, Pilz I, Dunbar C, Du Y, Jenkins NA, Copeland NG, Lüthi U, Hassan M, Thrasher AJ, Hoelzer D, von Kalle C, Seger R, Grez M. Correction of $\mathrm{X}$-linked chronic granulomatous disease by gene therapy, augmented by insertional activation of MDS1-EVI1, PRDM16 or SETBP1. Nat Med [Internet]. 2006 Apr;12(4):401-9. Available from: http://www.ncbi.nlm.nih.gov/pubmed/16582916

38. Raper SE, Chirmule N, Lee FS, Wivel NA, Bagg A, Gao G, Wilson JM, Batshaw ML. Fatal systemic inflammatory response syndrome in a ornithine transcarbamylase deficient patient following adenoviral gene transfer. Mol Genet Metab [Internet]. 80(1-2):148-58. Available from: http://www.ncbi.nlm.nih.gov/pubmed/14567964

39. Stein S, Ott MG, Schultze-Strasser S, Jauch A, Burwinkel B, Kinner A, Schmidt M, Krämer A, Schwäble J, Glimm H, Koehl U, Preiss C, Ball C, Martin H, Göhring G, Schwarzwaelder K, Hofmann W-K, Karakaya K, Tchatchou S, Yang R, Reinecke P, Kühlcke K, Schlegelberger B, Thrasher AJ, Hoelzer D, Seger R, von Kalle C, Grez M. Genomic instability and myelodysplasia with monosomy 7 consequent to EVI1 activation after gene therapy for chronic granulomatous disease. Nat Med [Internet]. 2010 Feb;16(2):198-204. Available

http://www.ncbi.nlm.nih.gov/pubmed/20098431

40. Booth C, Gaspar HB, Thrasher AJ. Treating Immunodeficiency through HSC Gene Therapy. Trends Mol Med [Internet]. 2016 Apr;22(4):317-27. Available from: http://www.ncbi.nlm.nih.gov/pubmed/26993219

41. Milone MC, O'Doherty U. Clinical use of lentiviral vectors. Leukemia [Internet]. 2018;32(7):1529-41. Available from: http://www.ncbi.nlm.nih.gov/pubmed/29654266

42. Cornetta K, Duffy L, Turtle CJ, Jensen M, Forman S, BinderScholl G, Fry T, Chew A, Maloney DG, June CH. Absence of Replication-Competent Lentivirus in the Clinic: Analysis of Infused T Cell Products. Mol Ther [Internet]. 2018 Jan 3 [cited 2020 May 4];26(1):280-8. Available from: http://www.ncbi.nlm.nih.gov/pubmed/28970045

43. Marcucci KT, Jadlowsky JK, Hwang WT, Suhoski-Davis M, Gonzalez VE, Kulikovskaya I, Gupta M, Lacey SF, Plesa G, Chew A, Melenhorst JJ, Levine BL, June CH. Retroviral and Lentiviral Safety Analysis of Gene-Modified T Cell Products and Infused HIV and Oncology Patients. Mol Ther. 2018 Jan 3;26(1):269-79.

44. Zufferey R, Nagy D, Mandel RJ, Naldini L, Trono D. Multiply attenuated lentiviral vector achieves efficient gene delivery in vivo. Nat Biotechnol. 1997;15(9):871-5.

45. Naldini L, Blömer U, Gallay P, Ory D, Mulligan R, Gage FH, Verma IM, Trono D. In vivo gene delivery and stable transduction of nondividing cells by a lentiviral vector. Science (80- ). 1996 Apr 12;272(5259):263-7.

46. Dull T, Zufferey R, Kelly M, Mandel RJ, Nguyen M, Trono D, Naldini L. A third-generation lentivirus vector with a conditional packaging system. J Virol [Internet]. 1998 Nov [cited 2020 Apr 22];72(11):8463-71. Available from: http://www.ncbi.nlm.nih.gov/pubmed/9765382 
bioRxiv preprint doi: https://doi.org/10.1101/2020.05.15.098335; this version posted November 23, 2020. The copyright holder for this preprint (which was not certified by peer review) is the author/funder, who has granted bioRxiv a license to display the preprint in perpetuity. It is made available under aCC-BY-NC-ND 4.0 International license.

Rive et al., 21 NOV 2020 - preprint copy version 2 - BioRxiv

\section{$\underline{\text { Figures }}$}

$\mathbf{A}$

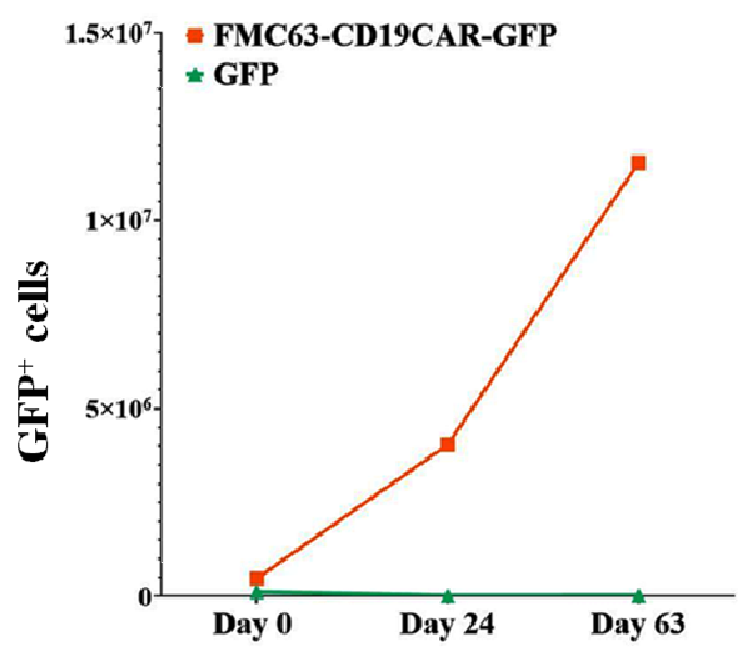

B

\section{- FMC63-CD19CAR-GFP vs CD19 ${ }^{+}$cell line (721.221) \\ - FMC63-CD19CAR-GFP vs CD19 cell line (K562)}

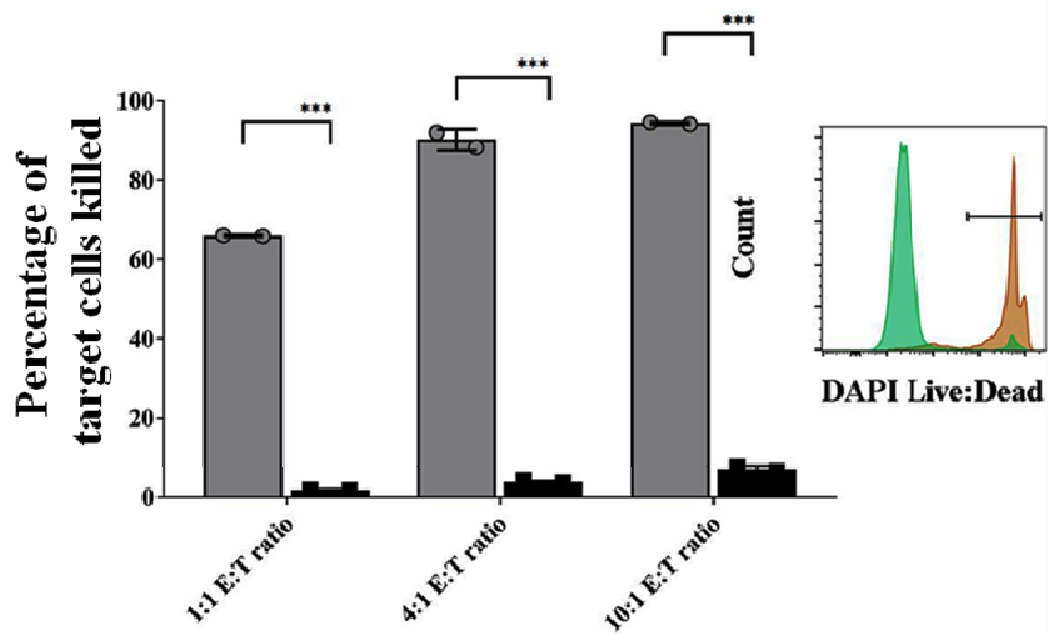

Figure 1: In vitro proliferation and cytolytic activity of human CAR-T cells. 1A: $5 \times 10^{5}$ Human healthy donor PBMCs were transduced with the FMC63-CD19CAR-GFP or GFP-only lentivirus at a MOI of 5. Transduced PBMC were then co-cultured with an excess of irradiated allogeneic PBMCs which provided a source of B cells expressing the CD19 antigen. The FMC63-CD19CAR-GFP human T cells showed a 120 fold expansion (orange, square), compared to GFP transduced cell (cyan, triangle). Figure 1B: 1x10 5 FMC63-CD19CAR-GFP human T cells from day 63 of the expansion assays were co-cultured with CD19+ (721.221) or CD19- (K562) target cells for 4h at effector to target (E:T) ratios of 1:1, 4:1, and 10:1. Target cell death was measured by flow cytometry using the non-viable cell marker DAPI [Figure S3]. Expanded human CAR-T cells showed robust and selective killing of the CD19+ 721.221 cells. At a ratio of 1:1 (E:T) the human CAR-T cells killed $66.0 \%+/-0.14 \%$ (mean $+/-$ SD) of B cells, at a ratio of 4:1 (E:T) the human CAR-T cells killed $90.2 \%+/-2.62 \%$ of B cells, and at a ratio of 10:1, the human CAR-T cells killed $94.4 \%+/-0.35 \%$ of B cells.Two-way ANOVA, Sidak's multiple comparison ***p<0.001. Inset: DAPI signal intensity in target cell populations, showing the shift to higher DAPI signal and corresponding target cell death in the $\mathrm{CD} 19^{+}$(orange) population compared to the lower DAPI signal and lack of cytolysis in the CD19- (cyan) population. 
bioRxiv preprint doi: https://doi.org/10.1101/2020.05.15.098335; this version posted November 23, 2020. The copyright holder for this preprint (which was not certified by peer review) is the author/funder, who has granted bioRxiv a license to display the preprint in perpetuity. It is made available under aCC-BY-NC-ND 4.0 International license.

A

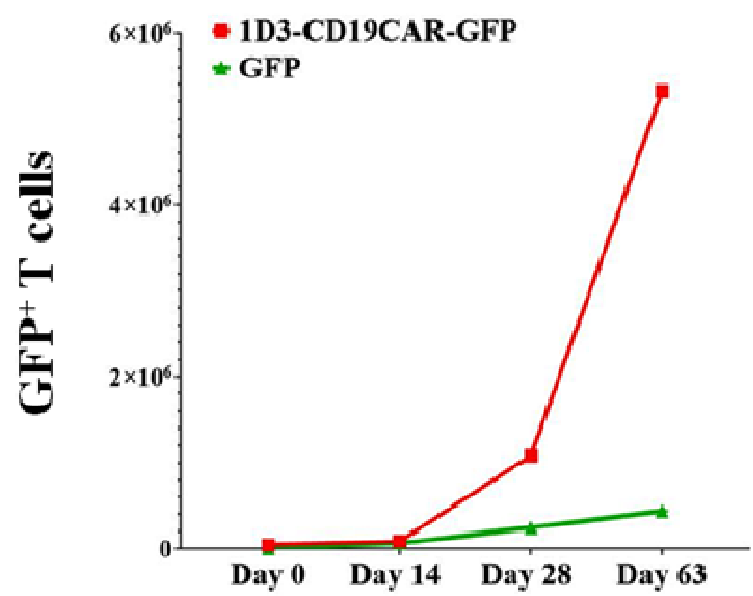

B

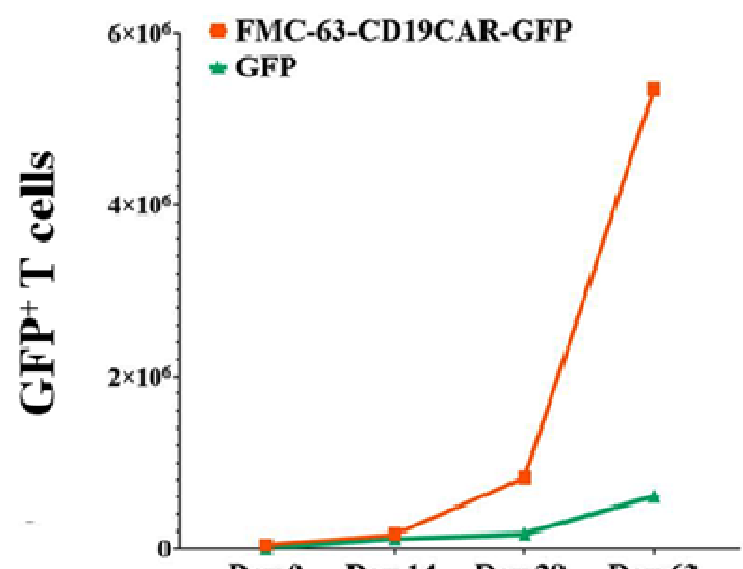

Day 0 Day 14 Day 28 Day 63

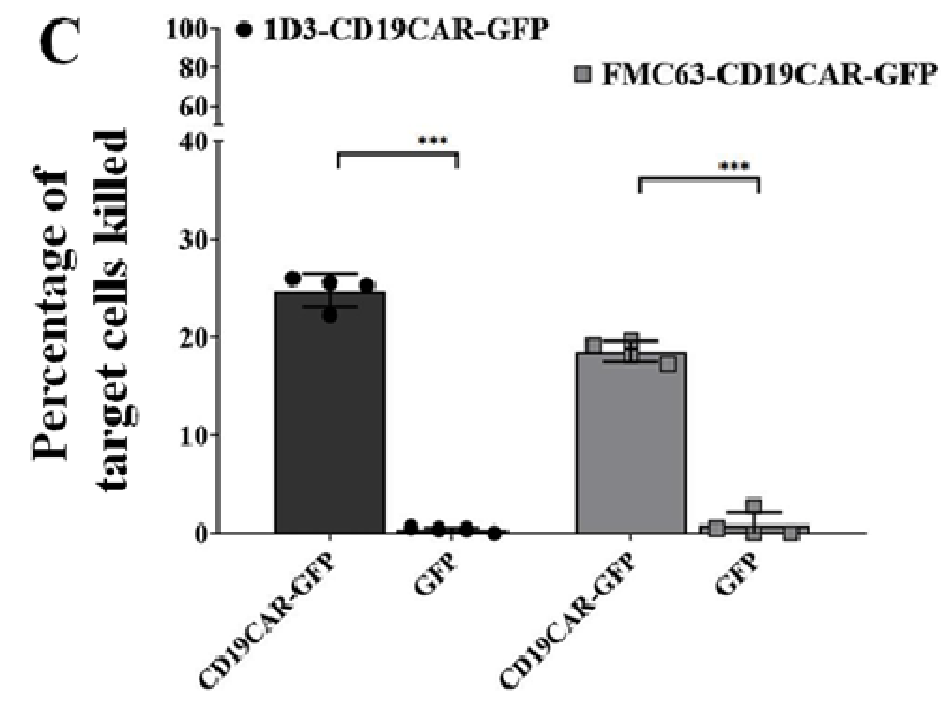

Figure 2: In vitro proliferation and cytolytic activity of murine CAR-T cells. 2A: $2.5 \times 10^{5}$ C57BL/6 splenocytes were transduced with 1 D3CD19CAR-GFP or GFP-only lentivirus at an MOI of 5. The transduced splenocytes were then co-cultured with an excess of irradiated C57BL/6 splenocytes which provided a source of B cells expressing the CD19 antigen. The 1D3-CD19CAR transduced splenocytes showed a 12.2+/- 0.09 (mean +/- SD) fold expansion (red, square), compared to GFP transduced (green, triangle) (p < 0.001 Tukey's multiple comparison test). Figure 2B: $2.5 \times 10^{5}$ C57BL/6 splenocytes were transduced with the FMC63-CD19CAR-GFP or GFP-only lentivirus at an MOI of 5. Splenocytes were then co-cultured with irradiated C57BL/6 splenocytes which provided a source of B cells expressing the CD19 antigen. The FMC63-CD19CAR transduced splenocytes showed a $8.8+/-0.03$ fold expansion (orange, square), compared to GFP transduced (cyan, triangle), (p < 0.001 Tukey's multiple comparison test). Figure 2C: $1 \times 10^{5}$ FMC63-CD19CAR-GFP or 1D3-CD19CAR murine T cells from day 63 of the expansion assays were co-cultured for 5 hours with target B cells, isolated from C57BL/6 splenocytes, at a E:T ratio of 1:1. Target cell death was measured through the shift in the FVS780 signal, measured by flow cytometry [Figure S4]. Expanded murine CAR-T cells showed robust and selective killing of murine B cells, with the 1D3-CD19CAR T cells killing $24.8+/-1.69 \%$ of B cells and the FMC63-CD19CAR T cells killing $18.5+/-1.08 \%$ of B cells in 5 hour co-cultures. Two-way ANOVA, Sidak's multiple comparison $* * * p<0.001$. 
bioRxiv preprint doi: https://doi.org/10.1101/2020.05.15.098335; this version posted November 23, 2020. The copyright holder for this preprint (which was not certified by peer review) is the author/funder, who has granted bioRxiv a license to display the preprint in perpetuity. It is made available under aCC-BY-NC-ND 4.0 International license.

Rive et al., 21 NOV 2020 - preprint copy version 2 - BioRxiv

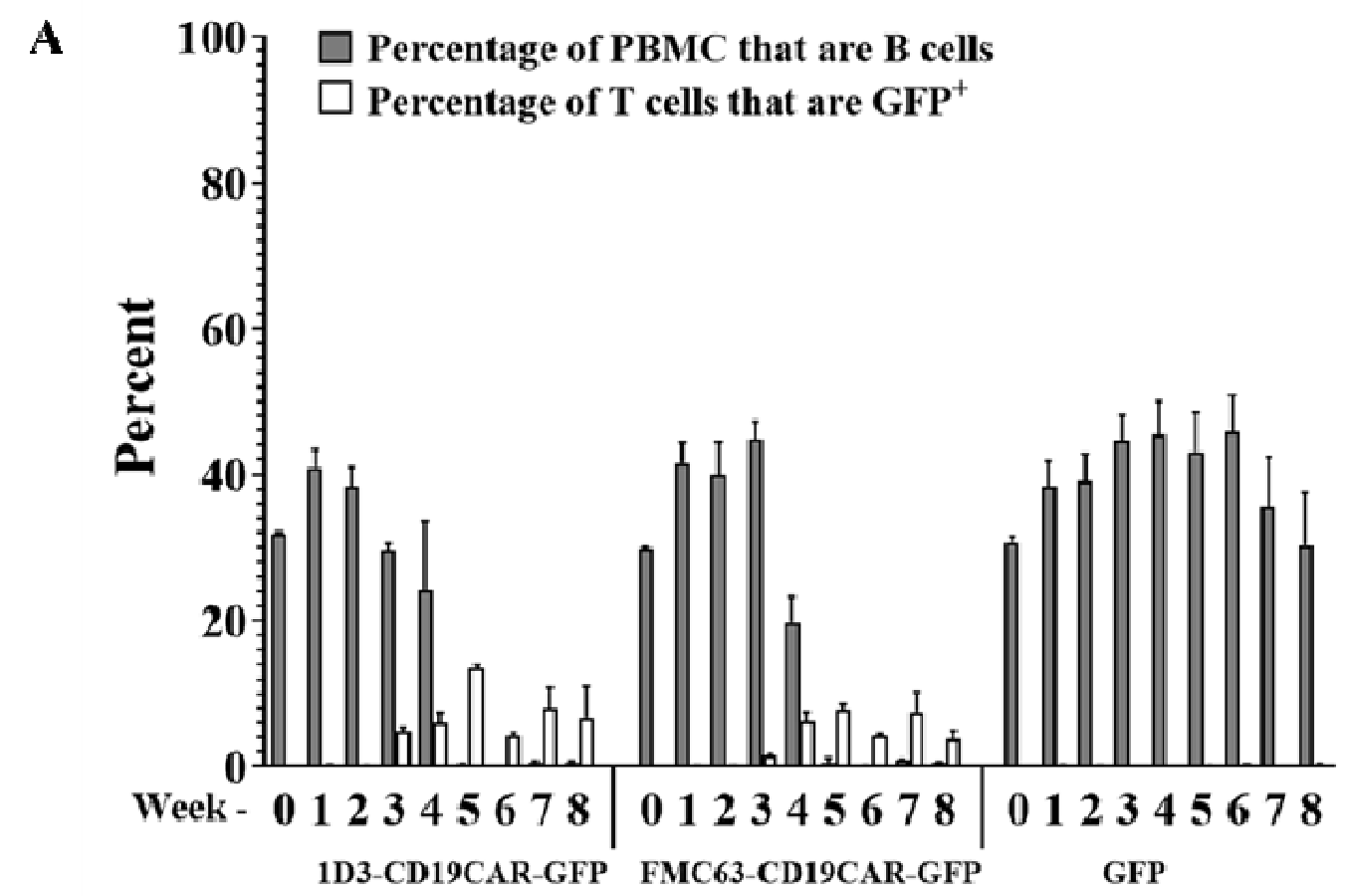

\section{FRIC63-CDI9CAR-GFP}

\section{ID3-C.DI9CAR-GFP}

B

Wesk 1 2 3
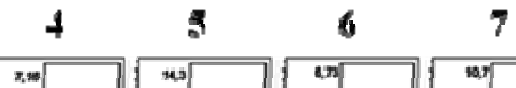

7

$\mathbf{8}$

GFP
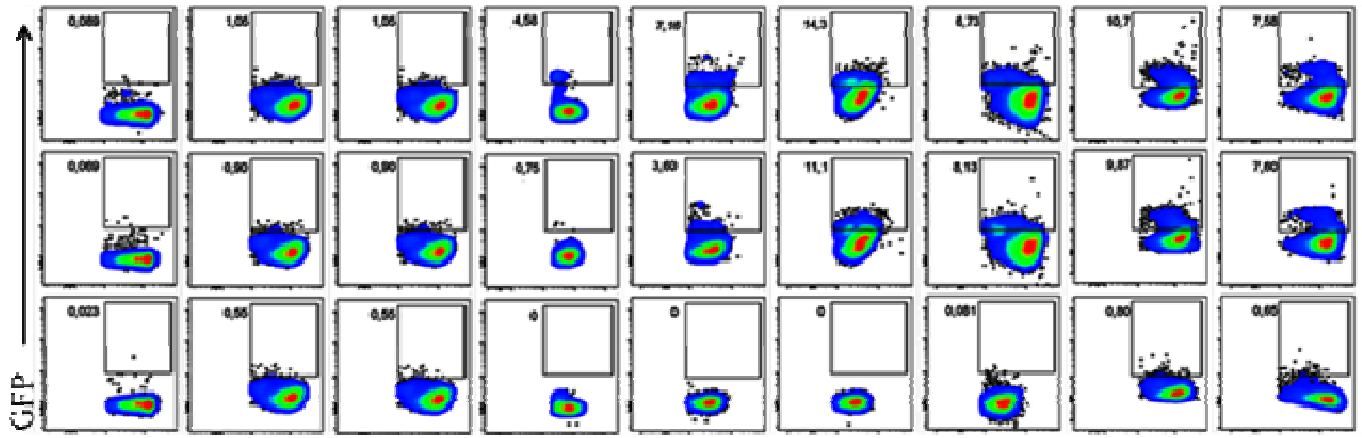

CDiKCDW. 2

Figure 3: The abundance of $\mathrm{CD20}^{+}, \mathrm{CD45R} / \mathrm{B220}^{+} \mathrm{B}$ cells and $\mathrm{GFP}^{+}, \mathrm{CD3}^{+}, \mathrm{CD} \mathrm{Co.}^{+} \mathrm{T}$ cells in peripheral blood of treated mice over time. Figure 3A: C57BL/6 wildtype mice were treated with a single IV injection of lentivirus (1.8-2 x10 7 IU in 200 $\mu 1$ PBS), to deliver either the $1 D 3-$ CD19CAR-GFP CAR, FMC63-CD19 CAR, or control (GFP-only). For mice treated with the ID3-CD19CAR lentivirus the GFP+ CAR-T cell count, as a percentage of all T cells present in PBMC, reached a maximum of $13.5+/-0.58 \%$ (mean $+/$ - SD) at week 5 . This was accompanied by B cell aplasia (grey bars) by week 5 which was maintained until the end of the experiment (week 8). For mice treated with the FMC63-CD19CAR lentivirus the $\mathrm{GFP}^{+} \mathrm{CAR}-\mathrm{T}$ count, as a percentage of all T cells present in PBMC, reached a maximum of $7.8+/-0.76 \%$ (mean $+/-\mathrm{SD}$ ) at week 5 and was accompanied by B cell aplasia (grey bars) by B cell aplasia which was maintained until the end of the experiment (week 8). Figure 3B: Representative flowgrams [Figure S5] from Figure 3A 
bioRxiv preprint doi: https://doi.org/10.1101/2020.05.15.098335; this version posted November 23, 2020. The copyright holder for this preprint (which was not certified by peer review) is the author/funder, who has granted bioRxiv a license to display the preprint in perpetuity. It is made available under aCC-BY-NC-ND 4.0 International license.

Rive et al., 21 NOV 2020 - preprint copy version 2 - BioRxiv
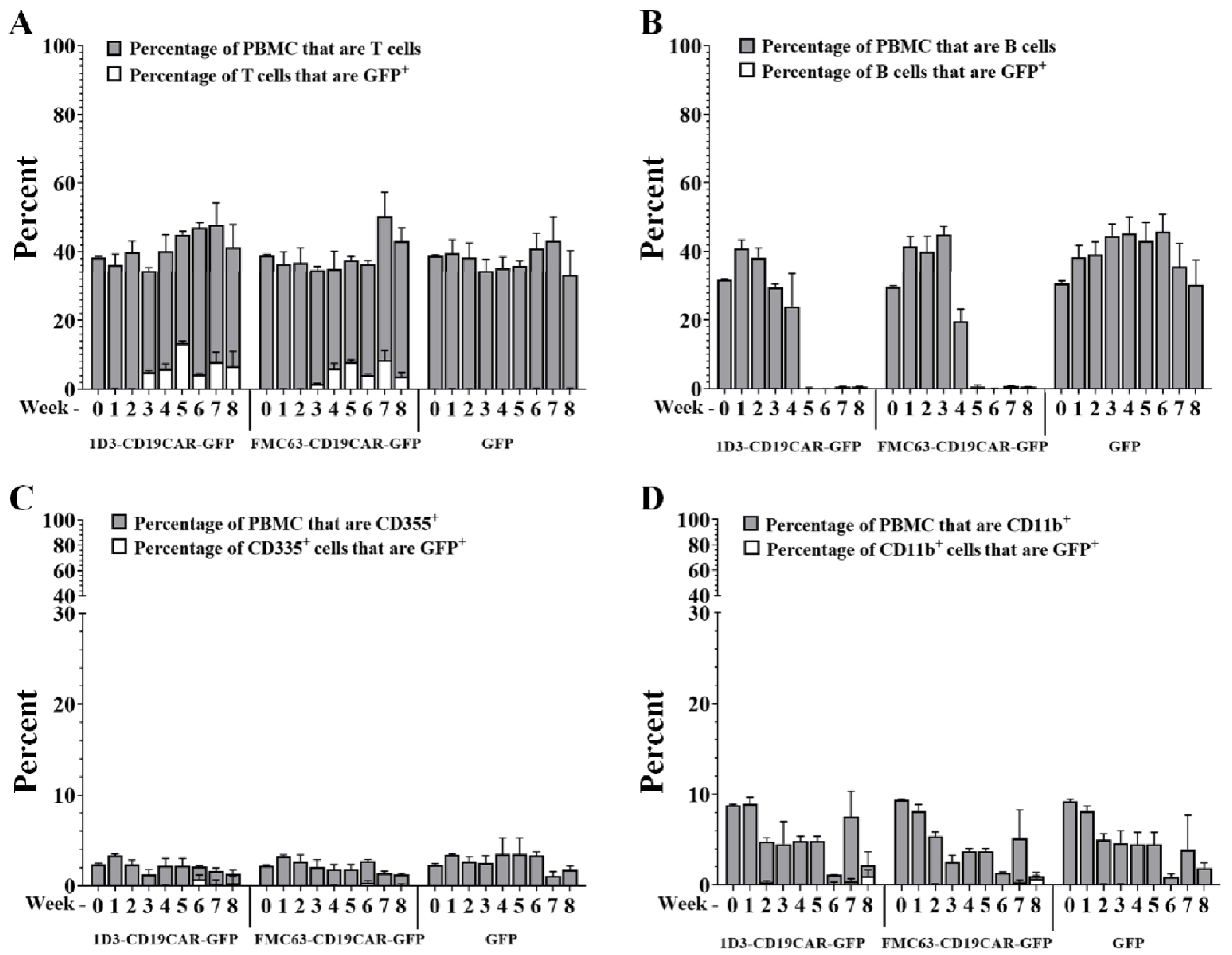

Figure 4: The abundance of transduced and untransduced immune cell subsets in peripheral blood of treated mice over time. C57BL/6

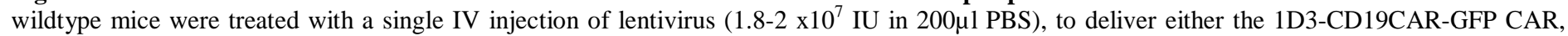
FMC63-CD19 CAR, or control (GFP-only). T cells, but not other immune cell subsets tested, show a substantial transduced cell population. Figure 4A: Total versus tranduced (GFP+) $\mathrm{CD}^{+}, \mathrm{CD} 90.2^{+} \mathrm{T}$ cells. Figure 4B: Total versus transduced (GFP+) CD20 ${ }^{+}, \mathrm{CD} 45 \mathrm{R} / \mathrm{B} 220^{+} \mathrm{B}$ cells. Figure 4C: Total versus transduced (GFP+) CD11 $\mathrm{b}^{+}$cells (macrophage and other non-T cells). Figure 4D: Total versus transduced $\left(\mathrm{GFP}^{+}\right) \mathrm{CD} 335^{+} \mathrm{NK}$ and $\mathrm{NKT}^{-}$ cells. Flow gating strategy outlined in Figure S5. 
bioRxiv preprint doi: https://doi.org/10.1101/2020.05.15.098335; this version posted November 23, 2020. The copyright holder for this preprint (which was not certified by peer review) is the author/funder, who has granted bioRxiv a license to display the preprint in perpetuity. It is made available under aCC-BY-NC-ND 4.0 International license.

Rive et al., 21 NOV 2020 - preprint copy version 2 - BioRxiv

Week 5

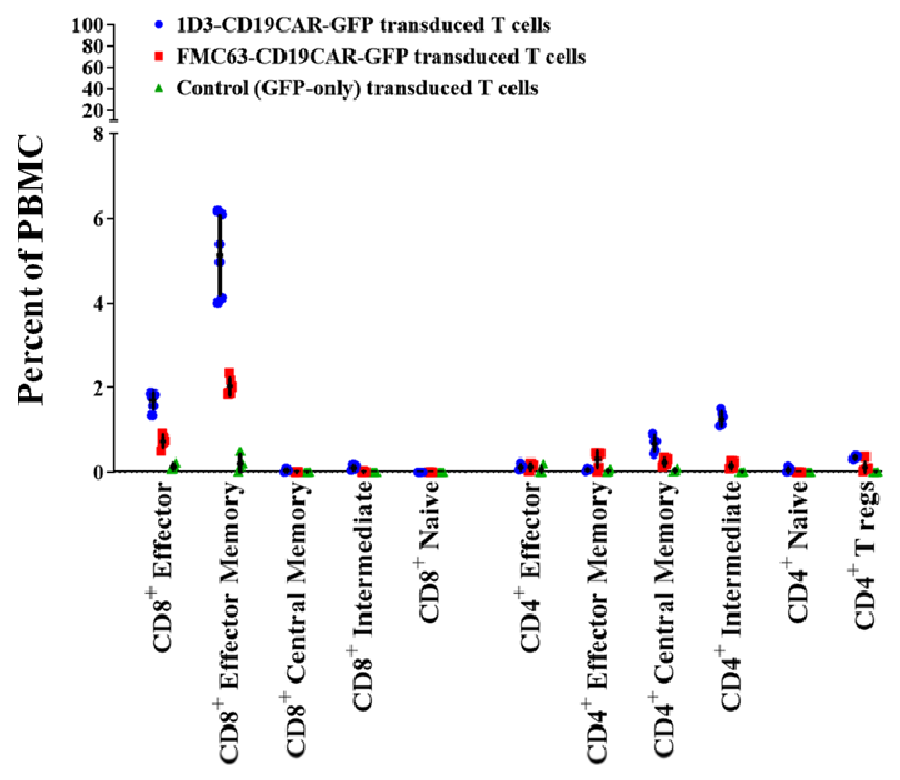

Week 8

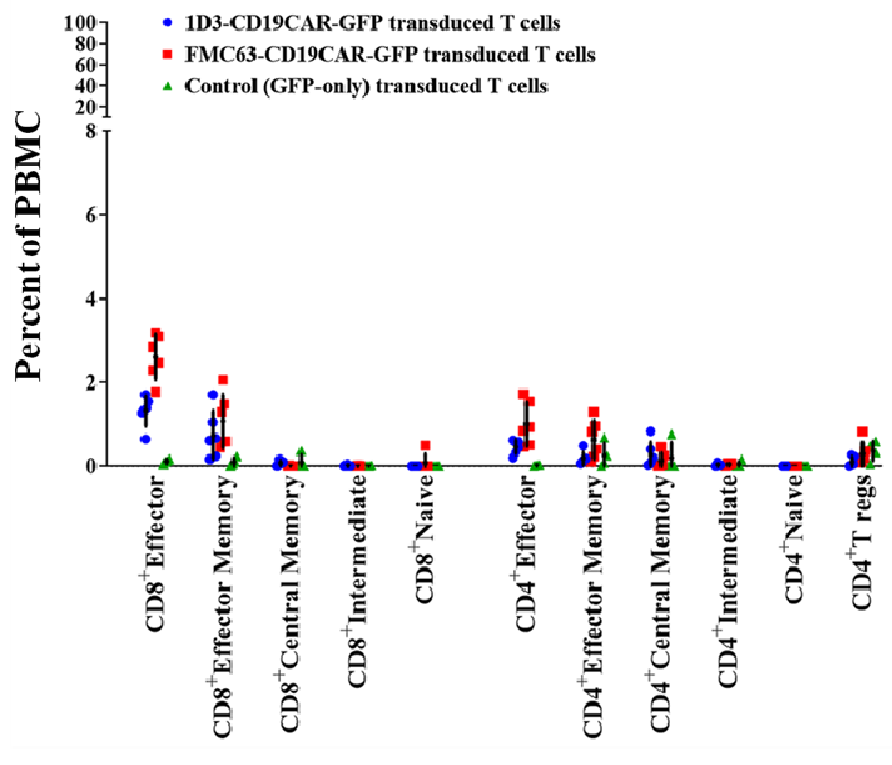

Figure 5: Immunophenotyping of 1D3-CD19CAR-GFP (blue, circle), FMC63-CD19 CAR-GFP (red, square) or control (GFP-only, green, triangle) transduced $\mathbf{T}$ cells in peripheral blood of treated mice. Values shown are the percentage of total CD3+, CD90.2+ T cells represented by each subtype $\left(\right.$ Effector $=\mathrm{CD} 44^{\text {high }}, \mathrm{CD} 62 \mathrm{~L}^{\text {low }} \mathrm{CD} 127^{\text {low }}$; effector memory $=\mathrm{CD} 44^{\text {high }}, \mathrm{CD} 62 \mathrm{~L}^{\text {low }} \mathrm{CD} 127^{\text {high }} ;$ central memory $=\mathrm{CD} 44^{\text {high }}, \mathrm{CD} 62 \mathrm{~L}^{\text {high }}$ $\mathrm{CD} 127^{\text {high }}$; intermediate phenotype $=\mathrm{CD} 44^{\text {high }} \mathrm{CD}_{2} \mathrm{~L}^{\text {high }} \mathrm{CD} 127^{\text {low }}$; naive $=\mathrm{CD} 44^{\text {low }}, \mathrm{CD}_{2} \mathrm{~L}^{\text {high }} \mathrm{CD} 127^{\text {high }}$; regulatory $\left.=\mathrm{CD} 4^{+}, \mathrm{FOXP} 3^{+}\right)$. Figure 5A: At week 5 the 1D3-CD19CAR-GFP T cells were predominantly CD ${ }^{+}$effector memory $\mathrm{T}$ cells $\left(5.1+/-0.9 \%\right.$ of total CD3 ${ }^{+} \mathrm{T}$ cells), effector $\mathrm{T}$ cells $\left(1.7+/-0.2 \%\right.$ of total $\mathrm{CD}^{+} \mathrm{T}$ cells $)$, and $\mathrm{CD} 4^{+}$intermediate $\mathrm{T}$ cells $\left(1.3+/-0.2 \%\right.$ of total CD $3^{+} \mathrm{T}$ cells). At week 5 the majority of FMC63CD19CAR-GFP T cells were CD8 ${ }^{+}$effector memory $\mathrm{T}$ cells $\left(2.0+/-0.2 \%\right.$ of total $\mathrm{CD}^{+} \mathrm{T}$ cells $)$ and effector $\mathrm{T}$ cells $\left(0.7+/-0.1 \%\right.$ of total CD $3^{+} \mathrm{T}$ cells). Figure 5B: At week 8, the majority of 1D3-CD19CAR-GFP T cells were effector memory T cells $\left(0.7+/-0.6 \%\right.$ of total CD3 ${ }^{+} \mathrm{T}$ cells $)$ and $\mathrm{CD}^{+}$effector $\mathrm{T}$ cells $\left(1.3+/-0.4 \%\right.$ of total $\mathrm{CD}^{+} \mathrm{T}$ cells). The majority of FMC63-CD19CAR-GFP T cells at week 8 were $\mathrm{CD} 8^{+}$effector memory $\mathrm{T}$ cells $\left(2.60+/-0.538 \%\right.$ of total $\mathrm{CD}^{+} \mathrm{T}$ cells $)$ and effector T cells $\left(1.1+/-0.6 \%\right.$ of total $\mathrm{CD}^{+} \mathrm{T}$ cells $)$. GFP expressing $\mathrm{CD} 4^{+}$FOXP $3^{+}$regulator $\mathrm{T}$ cells were present at both time points but comprised ofa small percentage $(<1 \%)$ of total T cells. Flow gating strategy outlined in Figure S6. 


\section{$\underline{\text { Supplementary Materials }}$}

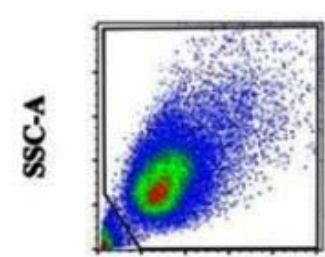

FSC-A

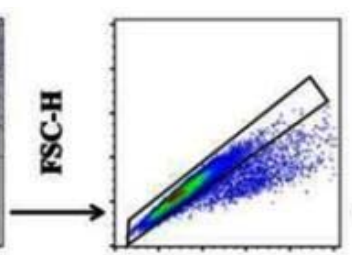

FSC-A

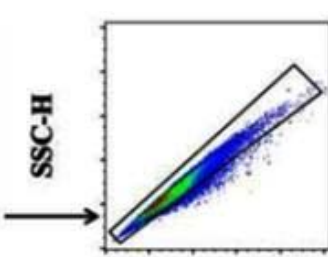

SSC-A

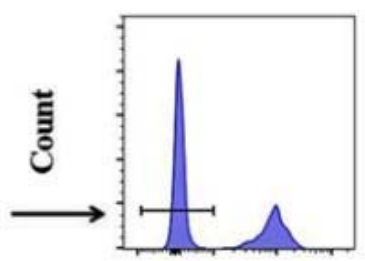

FSV780 Live:Dead

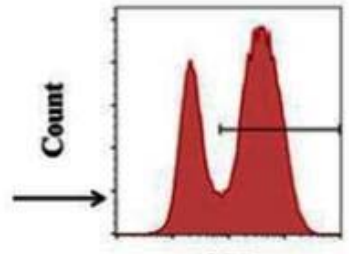

GFP

Figure S1: Viral supernatant titration flow gating protocol. After debris was eliminated by FSC-A vs. SSC-A gating, cell doublets and clumps were then eliminated by FSC-H vs. FSC-A gating followed by SSC-A vs. SSC-H gating. The live cells were determined by gating on the FVS780 negative cells which was on the GFP positive cells to determine the percentage of GFP expressing cells in order to measure transduction efficiency. The flow collected data was analysed using Flow Jo v10, for windows and GraphPad Prism software version 8.0.0 for windows (GraphPad Software, California, USA).

\section{A}

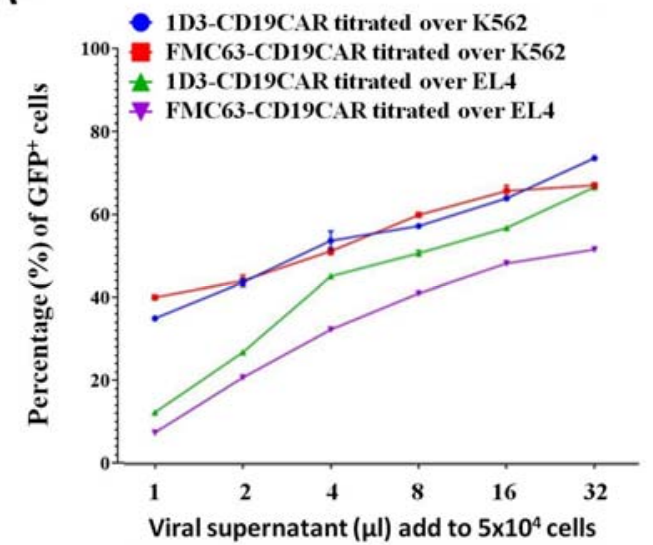

B



Figure S2: 1D3-CD19CAR-GFP, FMC63-CD19CAR-GFP, and GFP lentivirus transduction efficiency. Figure S2A: Titration of 1D3- CD19CARGFP and FMC63-CD19CAR-GFP viral supernatant titration over EL4 (green and purple, respectively) and K562 (red and blue, respectively) cell lines. While the transduction efficiency appears significantly better in the human K562s ( $\mathrm{p}<0.001$ ANOVA), the transduction of a murine cell line, EL4, indicates this lentivirus is able to transduce murine cells, albeit at a lower frequency. Figure S2B: $2.5 \times 10^{5}$ splenocytes were transduced with 1D3-CD19CAR-GFP, FMC63-CD19CAR-GFP, and GFP lentivirus at an MOI of 5 (calculated based on Figure S2A). The percentage (\%) of GFP , $^{+}$ $\mathrm{CD} 3+\mathrm{T}$ cells within the whole splenocyte sample was determined by assessing $3.0 \times 10^{4}$ cells via flow cytometry 72 hours after transduction with virus. 1D3-CD19CAR-GFP had a transduction efficiency of 17.1\% (+/-1.23\%), FMC63-CD19CAR-GFP 16.3\% (+/- 2.6\%), and GFP 12.2\% (+/- 
bioRxiv preprint doi: https://doi.org/10.1101/2020.05.15.098335; this version posted November 23, 2020. The copyright holder for this preprint (which was not certified by peer review) is the author/funder, who has granted bioRxiv a license to display the preprint in perpetuity. It is made available under aCC-BY-NC-ND 4.0 International license.

Rive et al., 21 NOV 2020 - preprint copy version 2 - BioRxiv

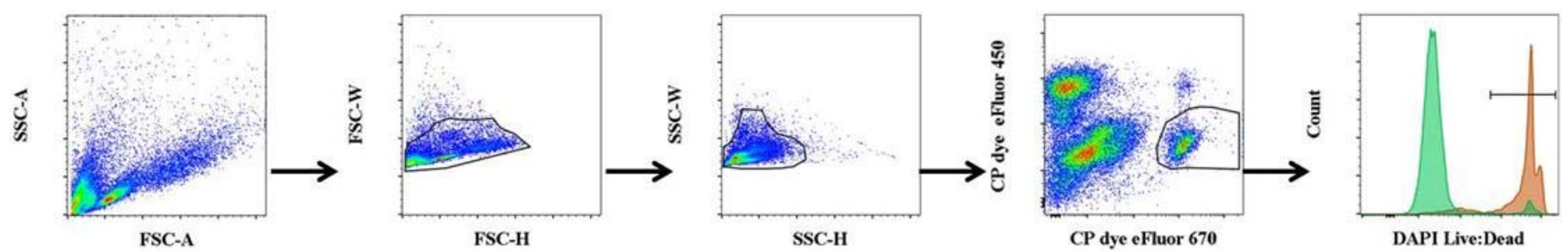

Figure S3: Flow cytometry gating protocol for the in vitro FMC63-CD19CAR-GFP T cell expansion and cytolytic activity using human PBMCs. Debris, cell doublets, and clumps were eliminated by FSC-A vs. FSC-H gating followed by SSC-A vs. SSC-H gating. The target cells, stained with $\mathrm{CP}$ eFluor 670 were selected for and gated on DAPI to obtain the percentage of live vs dead target cells. The flow collected data was analysed using Flow Jo v10, for windows and GraphPad Prism software version 8.0.0 for windows (GraphPad Software, California, USA) [Figure 1B].

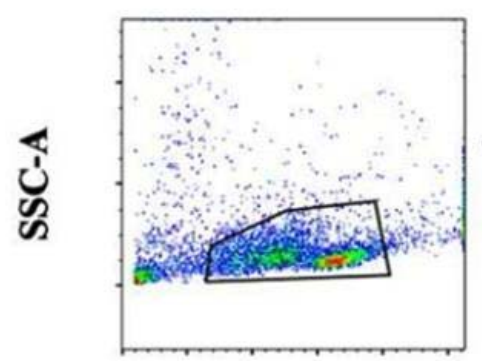

FSC-A

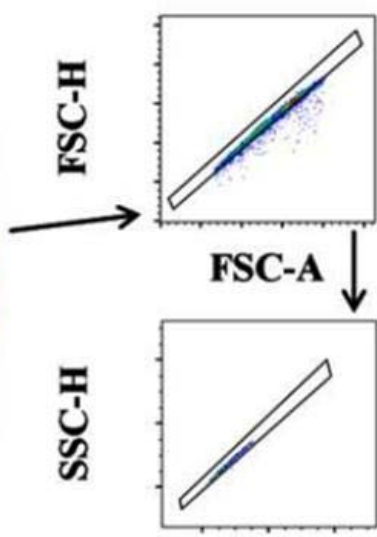

SSC-A

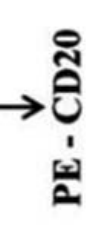

\section{eF}

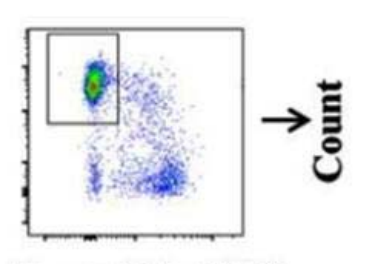

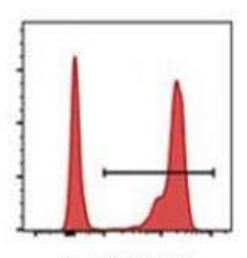

FVS780

Figure S4: In vitro 1D3- or FMC63-CD19CAR-GFP T cell cytolytic activity using C57BL/6 splenocytes. Debris, cell doublets, and clumps were eliminated by FCS-A vs SSC-A gating followed by FSC-A vs. FSC-H and SSC-A vs. SSC-H gating. T and B cells were then identified by CD3 vs. CD20 gating. CD20 positive cells were selected for and gated on FVS-780 to obtain the percentage of live vs. dead target cells. The flow collected data was analysed using Flow Jo v10, for windows and GraphPad Prism software version 8.0.0 for windows (GraphPad Software, California, USA) [Figure 2] 
bioRxiv preprint doi: https://doi.org/10.1101/2020.05.15.098335; this version posted November 23, 2020. The copyright holder for this preprint (which was not certified by peer review) is the author/funder, who has granted bioRxiv a license to display the preprint in perpetuity. It is made available under aCC-BY-NC-ND 4.0 International license.

Rive et al., 21 NOV 2020 - preprint copy version 2 - BioRxiv

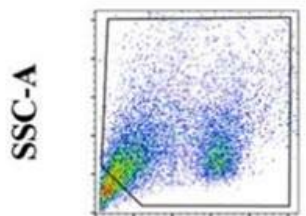

FSC-A
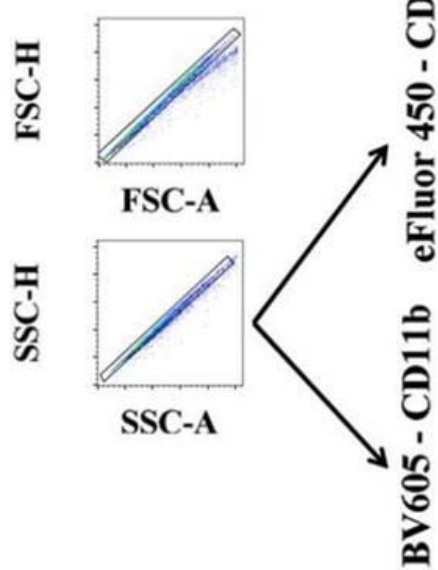

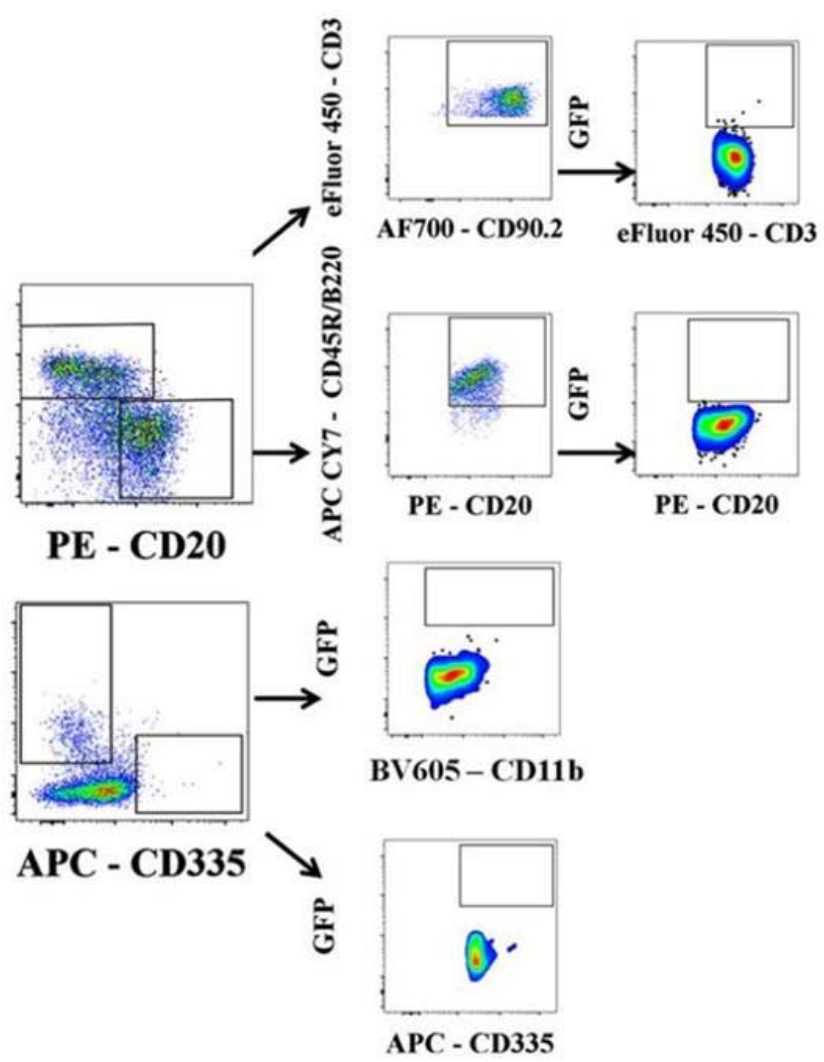

Figure S5: Flow gating protocol for the analysis of mouse blood pre- and post-treatment with lentiviruses. Debris was eliminated by FSC-A vs. SSC-A gating, cell doublets and clumps were then eliminated by FSC-H vs. FSC-A gating followed by SSC-A vs. SSC-H gating. T and B cells were then identified based on expression of CD3 or CD20 and NK cells and monocytes based on the expression of CD335 or CD11b, respectively. The CD3 positive cells were then gated for expression of CD90.2, and these CD3 and CD90.2 positive cells were gated for GFP expression (the CD19CAR reference gene marker). CD20 positive cells were gated for CD45R/B220 expression, and the CD20 and CD45R/B220 positive cells were then gated for GFP expression. NK cells (CD335) or monocytes (CD11b) were individually gated for GFP expression. The flow collected data was analysed using Flow Jo v10, for windows and GraphPad Prism software version 8.0.0 for windows (GraphPad Software, California, USA) [Figure 3 and Figure 4] 


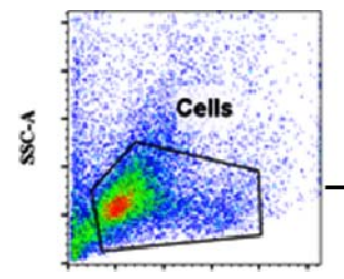

FsC-A

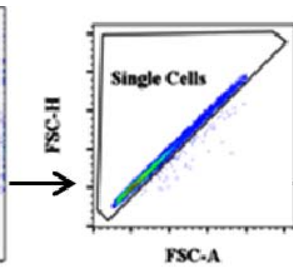

FSC.A

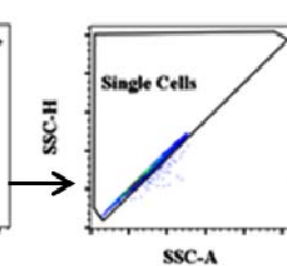

ssc-A
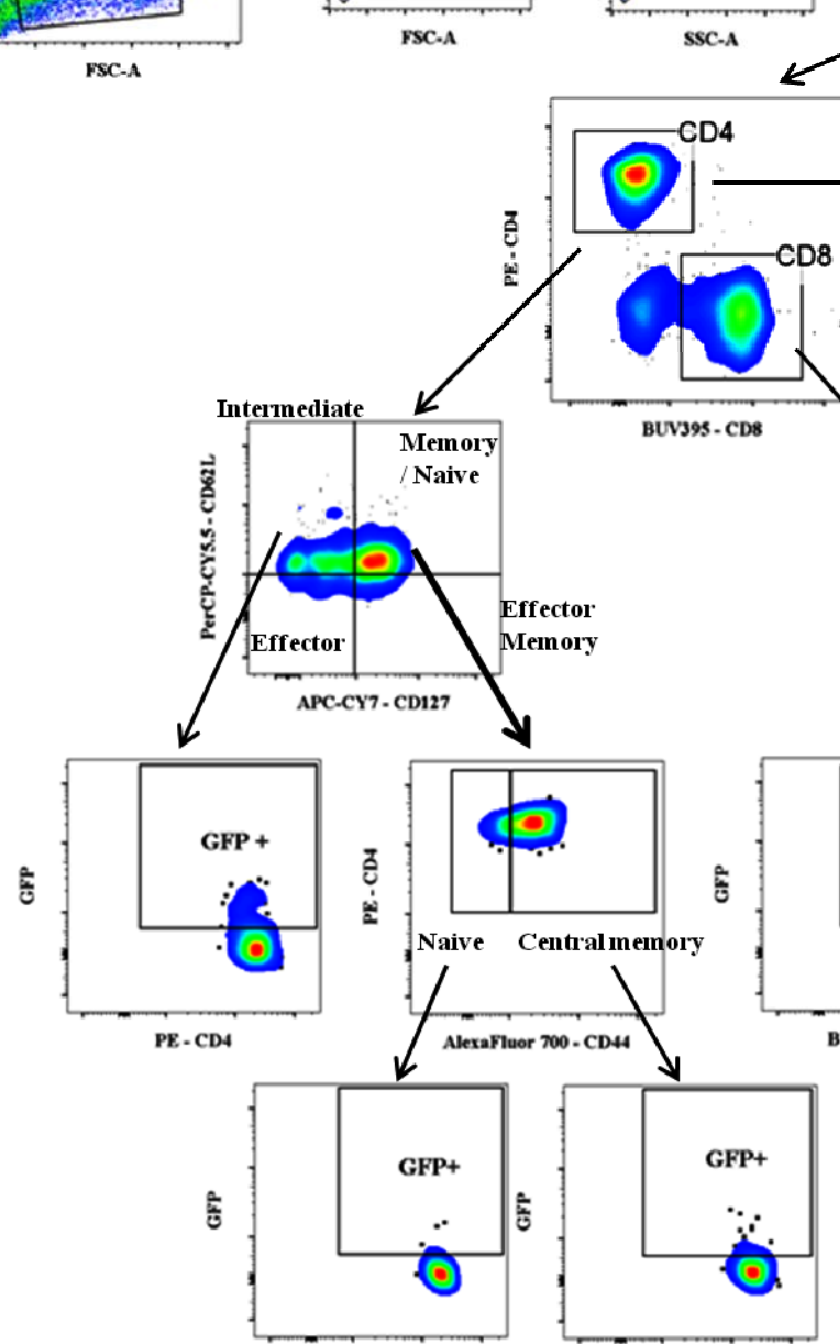

PE - CD4

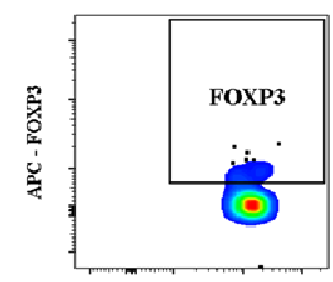

$\mathrm{PE}=\mathrm{CD} 4$

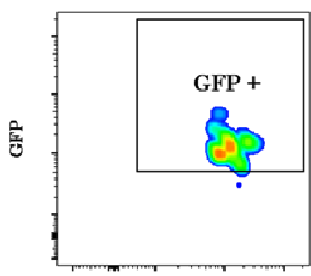

$\mathrm{PE}-\mathrm{CD} 4$

Figure S6: Flow gating protocol for the immunophenotyping analysis of murine T cells 5 and 8 weeks after lentiviral treatment. All cells were gated for in the FSC-A vs. SSC-A plot, cell doublets and clumps were then eliminated by FSC-H vs. FSC-A gating followed by SSC-A vs. SSC-H gating. $\mathrm{T}$ cells were then identified based on expression of CD3. The CD3 positive cells were then gated for expression of CD4 and CD8, and these CD3 ${ }^{+}$ and $\mathrm{CD}^{+}$or $\mathrm{CD}^{+}$positive cells were gated for CD127 and CD62L expression, allowing us to differentiate Central memory and naive cells, effector, and effector memory $\mathrm{T}$ cells. The Central Memory and Naive cells were then identified by their CD44 expression profile. Each of these subtypes were then looked at for GFP expression (the CD19CAR reference gene marker) indicated by the example plots above showing the positive expression of GFP. For regulatory T cells we plotted the CD4 ${ }^{+}$against the FOXP3, and then looked the number which expressed GFP. The flow collected data was analysed using Flow Jo v10, for windows and GraphPad Prism software version 8.0.0 for windows (GraphPad Software, California, USA) [Figure 5]. 
bioRxiv preprint doi: https://doi.org/10.1101/2020.05.15.098335; this version posted November 23, 2020. The copyright holder for this preprint (which was not certified by peer review) is the author/funder, who has granted bioRxiv a license to display the preprint in perpetuity. It is made available under aCC-BY-NC-ND 4.0 International license.

Rive et al., 21 NOV 2020 - preprint copy version 2 - BioRxiv

A

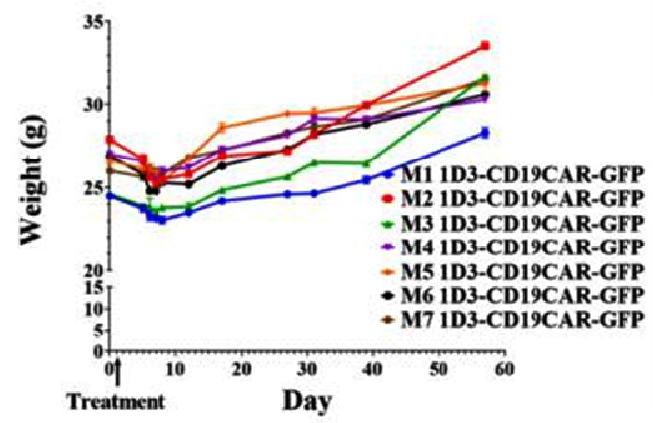

B

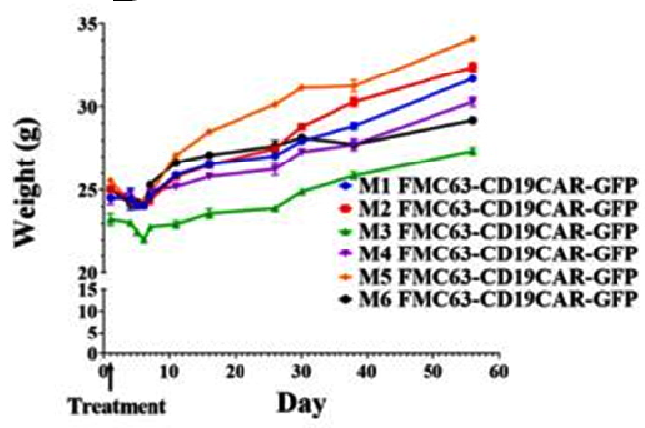

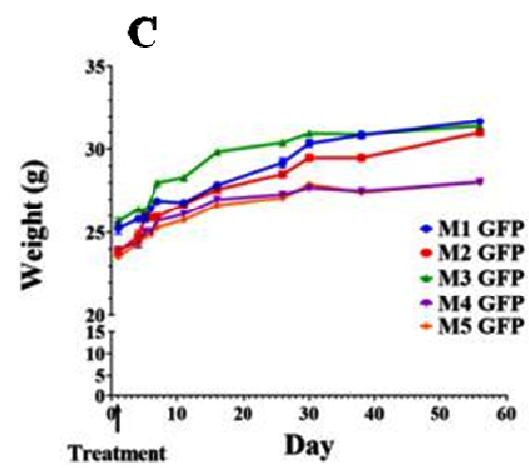

Figure S7: C57BL/6weights (grams) pre- and post treatment. Figure S7A: 1D3-CD19CAR-GFP lentivirus, Figure S7B: FMC63-CD19CAR-GFP lentivirus, and Figure S7C: GFP-only lentivirus or PBS. In Figure S7A and S7B, the mice that were treated with the 1D3-CD19CAR-GFP lentivirus or the FMC63-CD19CAR-GFP showed a 5.5 +/- 2.97\% (mean +/- SD) and 3.6 +/- 1.78\% reduction in weight, respectively, within 5-7 days after receiving treatment. Once the mice weights recovered, they exhibited no other visible adverse effects. 